\title{
Identification and Characterization of a Novel (115 kDa) Neurofilament-associated Kinase
}

\author{
Jinsong Xiao ${ }^{1}$ and Mervyn J. Monteiro ${ }^{2}$ \\ ${ }^{1}$ Molecular and Cell Biology Graduate Program, ${ }^{2}$ Medical Biotechnology Center of the Maryland Biotechnology Institute \\ and Department of Neurology, The University of Maryland School of Medicine, Baltimore, Maryland 21201
}

Neurofilaments (NF), the major cytoskeletal component in neuronal cells, are one of the most highly phosphorylated proteins expressed in brain. Apart from the structural role NFs play in maintaining neuronal architecture, little else is known of their function. We describe here evidence suggesting that NF may support many other proteins in the neuronal axoplasm including protein kinases. In order to isolate proteins that bind NF, we first expressed the carboxyl-terminal tail domain of the mouse high-molecular-weight NF subunit (NF-H) as a fusion protein in bacteria and then used this portion of NF-H as a ligand in affinity chromatography. A number of different proteins were isolated from mouse brain lysate that specifically bound to the NF-H column and that did not bind to a control column to which BSA was bound as a ligand. The proteins eluted from the NF-H column contained kinases able to phosphorylate NF proteins efficiently in vitro. We characterized these kinases further by separating proteins on denaturing polyacrylamide gels and reconstituting kinase activity in situ. Using this assay we identified a number of individual kinases including a $115 \mathrm{kDa}$ polypeptide that showed a significant preference for NF proteins as substrate. Native NF was found to be the best substrate for the $115 \mathrm{kDa}$ kinase, followed by a bacterially expressed NF-H nonfusion protein, and NF-H fusion protein. However, low-molecular-weight NF subunit (NF-L) was a poor substrate. Two different NF monoclonal antibodies, SMI31 and SMI32 (Sternberger Monoclonal Inc.), were used to demonstrate further that the $115 \mathrm{kDa}$ kinase is associated with NF in vivo. The kinase was coimmunoprecipitated along with NF by the two NF monoclonal antibodies but appeared to be preferentially associated with phosphorylated forms of NF. We discuss here some of the novel properties of the 115 kDa NF-associated kinase we have termed NAK 115 (for NFassociated kinase with a molecular weight of $115 \mathrm{kDa}$ ).

[Key words: neurofilaments, affinity chromatography, phosphorylation, protein kinases, immunoprecipitation]

\footnotetext{
Received June 15, 1993; revised Aug. 30, 1993; accepted Sept. 14, 1993.
}

This work was supported by grants from the American Federation for Aging Research, American Health Assistance Foundation, NIH AG11386, and Bressler Pangborn Fund to M.J.M. We thank Dr. Harish Pant (NIH), Dr. Ron Liem, and Lisa $\mathrm{Gu}$ for gifts of rat NF preparation, rat NF-M and NF-H cDNAs, and purified bNF-L, respectively. We also thank Dr. Ann Pluta, Robyn Starr, and Susan Janicki for insightful comments on the manuscript.

Correspondence should be addressed to Mervyn J. Monteiro, Ph.D., University of Maryland, MBC and Department of Neurology, Room N4 46 North Hospital, 22 South Greene Street, Baltimore, MD 21201.

Copyright (C) 1994 Society for Neuroscience $0270-6474 / 94 / 141820-14 \$ 05.00 / 0$
The neuronal cytoskeleton is composed of actin filaments, intermediate filaments, and microtubules. The most abundant intermediate-filament components expressed in mature neuronal cells are neurofilaments (NF). Mammalian NF are typically composed of three subunits, NF-L (68 kDa), NF-M (160 $\mathrm{kDa}$ ), and NF-H (200 kDa) (Hoffman and Lasek, 1975; for reviews, see Fliegner and Liem, 1991; Shaw, 1991). The three subunits differ from onc another in length of their carboxylterminal sequences, which are modified by phosphorylation. In fact, NF-M and NF-H are among the most heavily phosphorylated proteins found in brain (for review, see Nixon and Sihag, 1991).

The major site phosphorylated in both NF-M and NF-H is the sequence Lys-Ser-Pro-Val (other repeats have either Ala/ Glu/Thr/Leu in place of the Val) that is present as 5-9 and 3952 copies, respectively, in the carboxyl-terminal regions of the molecules (see Fliegner and Liem, 1991). In fact, both molecules are phosphorylated at a molar ratio that approximates the occurrence of the repeats (Julien and Mushynski, 1982, 1983; Carden et al., 1985; Geisler et al., 1987). A number of other sequences on NF are also phosphorylated (see Xu et al., 1990, 1992; Fliegner and Liem, 1991; Nixon and Sihag, 1991). Further, there is both developmental regulation of NF expression and phosphorylation during development (Shaw and Weber, 1982; Julien et al., 1986; Carden et al., 1987; see also Fliegner and Liem, 1991; Nixon and Sihag, 1991). The consequence of phosphorylation on NF function is not known. However, in a number of neurodegenerative diseases in which neuronal structure is affected, NF phosphorylation was shown to be significantly altered (Sternberger et al., 1985; Schmidt et al., 1987; Zhang et al., 1989; Arai et al., 1990; Trojanowski et al., 1993).

There appear to be several kinases that phosphorylate NF in vitro, including some that copurify with NF preparations (ToruDelbauffe and Pierre, 1983; Pant et al., 1986; Toru-Delbauffe et al., 1986; Caputo et al., 1989; Dosemeci et al., 1990; Floyd et al., 1991; Nixon and Sihag, 1991). Kinases that phosphorylate NF in vitro can be divided into second messenger-dependent kinases and second messenger-independent kinases. The former appear to phosphorylate the "head" domain of NF whereas the latter appear to phosphorylate the "tail" domain (for review, see Nixon and Sihag, 1991). The second messenger-dependent kinases include calcium- and calmodulin-dependent as well as cAMP- and phosphatidylserine-dependent kinases. Recently, evidence was also obtained for a role of both protein kinase $A$ (PKA) as well as protein kinase C (PKC) in phosphorylation of NF after axotomy (Hall and Kosik, 1993).

Roder and Ingram (1991) have identified two kinases, PK36 and PK40, which phosphorylate NF-H, NF-M, and tau proteins. 
Phosphorylation of NF-H and NF-M by these kinases reduced the mobility of the NF proteins on SDS-polyacrylamide gels. PK36 and PK40 were found to be second messenger-independent kinases that did not autophosphorylate or associate with the cytoskeleton.

Another well-characterized NF kinase is an activity that had marked specificity for NF-H (Wible et al., 1989). This activity copurified with a $67 \mathrm{kDa}$ doublet protein. The kinase was found to be unrelated to either PKA, PKC, $\mathrm{Ca}^{2+} /$ calmodulin-dependent kinase, or casein kinase I and II. It was shown to be an effector-independent kinase that did not autophosphorylate. An interesting feature of the kinase was its specificity for NF-H but not for NF-M or NF-L substrates. The specificity for NF-H was limited only for partially dephosphorylated NF-H. Thus, the kinase was unable to phosphorylate completely dephosphorylated NF-H. These results suggest that NF phosphorylation occurs in a processive manner and that multiple kinases may phosphorylate NF.

Using NF-H affinity chromatography in combination with an in situ gel kinase assay, we have identified a novel kinase from mouse brain extracts that appears to differ in many respects from any of the other identified NF kinases. This kinase has a molecular weight of $115 \mathrm{kDa}$, can autophosphorylate, and is found associated with NF. Furthermore, an apparently related kinase having similar properties was identified in human brain lysates, indicating that this kinase may be important in neuronal function.

\section{Materials and Methods}

Expression of NF proteins in bacteria. NF proteins were expressed in bacteria using pATH expression plasmids. Two different portions of NF-H were expressed: the tail region as a fusion protein, and almost the entire coding sequence as a nonfusion protein.

To express the fusion protein, the mouse NF-H genomic clone (Julien et al., 1988) was digested with BstY1, and the approximately 2.5 kilobase pair fragment spanning codons 458 to the stop codon, which includes almost the entire tail domain of $\mathrm{NF}-\mathrm{H}$, was ligated in frame into the BamHI site of the trpE expression vector pATH1 (Koerner et al., 1991). This recombinant produces a fusion polypeptide of 323 amino acids (aa) of trpE sequences, 11 aa of polylinker sequences, and 629 aa of NF-H sequences.

The method used to express $\mathrm{NF}-\mathrm{H}$ as a nonfusion protein in bacteria has been described (Mercy et al., 1992). This clone expresses 1004 aa of rat NF-H, from codon 69 until the stop codon (see Chin and Liem, 1990; Mercy et al., 1992)

In order to express the complete NF-M polypeptide in bacteria, two DNA primers were used to amplify by the polymerase chain reaction (PCR) a specific portion of rat NF-M cDNA (a kind gift from Dr. Ronald K. H. Liem, Columbia University, NY). The forward primer began at the first base of the third codon of NF-M (5'-TACACGCTGGACTCGCT-3') (Napolitano et al., 1987), and the reverse primer (5'CCGCGAAGCTTGCAATGGACTCCGATC-3') was complementary to the part of the coding strand just downstream of the stop codon. The PCR product of about 2.5 kilo-base pairs was blunt-end ligated with NruI-digested pATH10.1 plasmid DNA (Mercy et al., 1992) and recombinants containing the insert in the appropriate orientation were selected by restriction mapping. These recombinants should express the complete NF-M polypeptide as a nonfusion polypeptide.

The entire mouse NF-I polypeptide was expressed in bacteria as a nonfusion protein, as described previously (Mercy et al., 1992).

$\mathrm{NF}$ cDNAs under the control of the $\operatorname{trp} E$ regulatory sequences were expressed in Escherichia coli $C A G 156$ by addition of indole acrylic acid (IAA), essentially as described by Mercy et al. (1992).

Purification of NF proteins expressed in bacteria. Bacteria induced from a 4 liter culture were suspended in $50 \mathrm{ml}$ of $25 \mathrm{~mm}$ Tris- $\mathrm{HCl}$ (pH 7.0), $5 \mathrm{~mm}$ EDTA, and $1 \mathrm{~mm}$ EGTA. Lysozyme was then added to 1 $\mathrm{mg} / \mathrm{ml}$ and the suspension incubated on ice for $1 \mathrm{hr}$. Bacteria were then lysed by adding NP40 to $0.1 \%$ and urea to $6 \mathrm{M}$. The lysate was sonicated to shear DNA, which was then clarified by centrifugation at $20,000 \times$ $g$ for $20 \mathrm{~min}$. The supernatant was applied to a pre-equilibrated DE52 (Whatman, Hillsboro, OR) column. The column was then washed with buffer A $16 \mathrm{~m}$ urea, $1 \mathrm{~mm}$ EGTA, $1 \mathrm{~mm}$ dithiothreitol (DTT), $10 \mathrm{~mm}$ BisTris, $\mathrm{pH}$ 6.5], and the proteins that bound to the column were eluted with a linear gradient of $\mathrm{NaCl}(0-0.5 \mathrm{M})$ in buffer $\mathrm{A}$. This procedure was used to purify bacterially expressed NF-H fusion protein (bNF-H), the bacterially expressed NF-H nonfusion protein, and NF-L. This single DE52 chromatography procedure yielded approximately $100 \mathrm{mg}$ of approximately $65 \%$ pure bNF-H protein from 4 liters of an induced bacterial culture (purity was determined by scanning the bNF-H fraction with a laser densitometer after separation by SDS-PAGE and staining with Coomassic bluc; Fig. $1 C$ ). Howcver, in order to purify NF-II nonfusion protein or $\mathrm{bNF}-\mathrm{L}$, additional purification was necessary.

To purify the bacterially expressed NF-H nonfusion protein, fractions from the DE52 column were dialyzed against $8 \mathrm{M}$ urea and adjusted with ampholytes ( $\mathrm{pH} 3-10)$ to $1 \%$, and the proteins were separated by preparative isoelectric focusing using the Bio-Rad Rotofor Cell. Using this procedure, NF-H nonfusion protein fractionated free of other bacterial proteins in the $\mathrm{pH} 7.0-7.5$ range of the $\mathrm{pH} 3-10$ gradient that was established (see Fig. $1 E$ ).

bNF-L was purified by dialyzing fractions from the DE52 column against low pH buffer [150 mM NaCl, $1 \mathrm{~mm}$ EGTA, 1 mM DTT, and $25 \mathrm{~mm} 2-[N$-morpholinobethanesulfonic acid (MES), $\mathrm{pH} 6.5]$ for $15 \mathrm{hr}$ at $4^{\circ} \mathrm{C}$. During this procedure bNF-L precipitated, probably because the subunits self-assembled to form filaments, which were collected by centrifugation at $100,000 \times g$ for $20 \mathrm{~min}$. Although somc contaminating $E$. coli proteins were still present after the first centrifugation step, they were subsequently removed upon repeated disassembly (in $6 \mathrm{M}$ urea) and reassembly.

The purified bacterially expressed NF proteins were dialyzed extensively against $25 \mathrm{~mm} \mathrm{MES}$, pH 6.5, $1 \mathrm{~mm}$ EGTA, and 1 mM EDTA prior to using the proteins for in vitro and in situ gel kinase assays.

Preparation of mouse brain extract. Approximately $25 \mathrm{gm}$ of CD1 mouse brain tissue was homogenized in extraction buffer $(100 \mathrm{mM} \mathrm{KCl}$, $0.3 \%$ NP40, $1 \mathrm{~mm}$ EDTA, $1 \mathrm{~mm}$ EGTA, $1 \mathrm{~mm}$ DTT, $1 \mathrm{~mm}$ aprotonin, $1 \mathrm{~mm}$ leupeptin, $1 \mathrm{~mm}$ bactricin, and $50 \mathrm{~mm}$ HEPES, $\mathrm{pH} 7.5$ ). The lysate was centrifuged at $40,000 \times g$ for $30 \mathrm{~min}$ to remove particulate material, and the supernatant adjusted with buffer so that the final concentrations of $\mathrm{KCl}$ and NP40 were $50 \mathrm{~mm}$ and $0.15 \%$, respectively. This extract was used to isolate NF-binding proteins by affinity chromatography.

Isolation of NF-binding proteins by affinity chromatography. Purified bacterially expressed NF-H fusion protein $(10 \mathrm{mg})$ and BSA (10 mg; Sigma) were each covalently coupled to $12 \mathrm{ml}$ of activated CH-Sepharose 4B (Pharmacia) according to the coupling instructions provided by the manufacturer. The Sepharose-coupled protein matrices were packed into two columns. The columns were washed with $1 \mathbf{M}$ ethanolamine ( $\mathrm{pH} 8.0$ ) to inactivate remaining $\mathrm{CH}$-Sepharose binding sites. Extract buffer containing $5 \% \mathrm{BSA}, 50 \mathrm{mM} \mathrm{KCl}$, and $0.1 \% \mathrm{NP} 40$ was then circulated over both columns to block further the nonspecific protein hinding sites. Mouse brain extract was then pumped over the two affinity columns overnight. The eluate from the columns was collected into a common reservoir and was circulated over both columns repeatedly (Fig. 2A). The columns were then washed extensively, until no trace of protein was detected in the eluate by UV absorbance at 280 $\mathrm{nm}$. Proteins bound to the columns were then eluted with $10 \mathrm{ml}$ portions of the following solutions made in extract buffer containing $3 \mathrm{~mm} \mathrm{MgCl}$ : (1) $5 \mathrm{~mm}$ ATP, (2) $100 \mathrm{~mm} \mathrm{KCl,} \mathrm{(3)} 300 \mathrm{~mm} \mathrm{KCl}$, (4) $500 \mathrm{~mm} \mathrm{KCl}$, and (5) $1 \mathrm{M} \mathrm{KCl}$. The fractions eluted from the columns were adjusted by addition of glycerol to $50 \%$ and stored at $-85^{\circ} \mathrm{C}$. Portions of the fractions were either analyzed by SDS-PAGE, immunoblotted, or assayed for kinase activity by in vitro and in situ gel kinase assays as described below.

SDS gel electrophoresis and immunoblotting. Protein samples were boiled in Laemmli loading buffer containing 2\% 2-mercaptoethanol for $10 \mathrm{~min}$ and separated by electrophoresis through $6.5-10 \%$ SDS polyacrylamide gels (Laemmli, 1970). The fractionated proteins were either visualized by staining gels with Coomassie blue, or in some cases by silver (Morrissey, 1981). For immunoblotting, gels after electrophoresis were transferred to nitrocellulose filters by electroblotting and incubated for $17-20 \mathrm{hr}$ at $4^{\circ} \mathrm{C}$ with appropriate antibodies in a solution containing $5 \%$ Carnation nonfat milk in TBS buffer $(10 \mathrm{~mm}$ Tris- $\mathrm{HCl}, \mathrm{pH} 7.2,150$ $\mathrm{mm} \mathrm{NaCl}$ ). After incubation the filters were washed with $0.2 \% \mathrm{NP} 40$, $0.1 \%$ milk in TBS buffer. Filters that were reacted with mouse monoclonal antibodies were further incubated for $2 \mathrm{hr}$ at $25^{\circ} \mathrm{C}$ with rabbit 

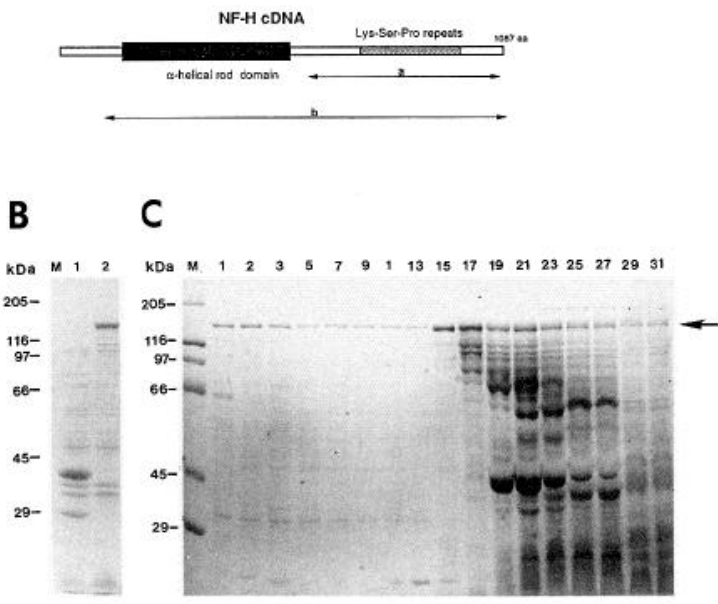

D

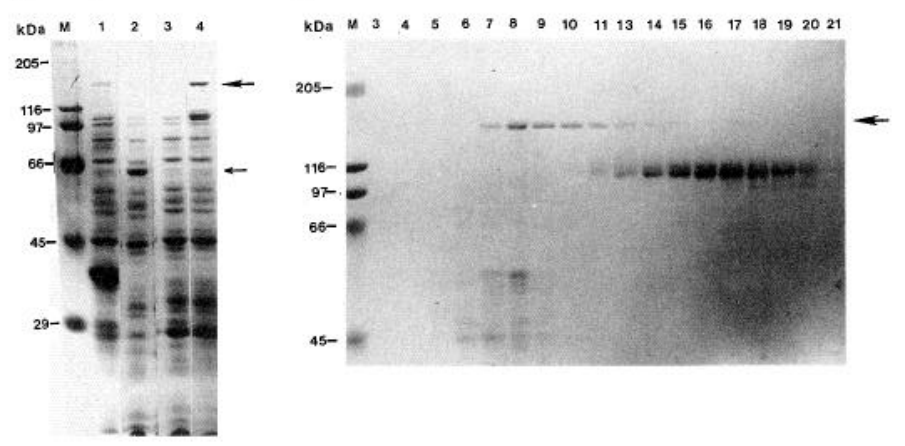

\section{$\mathbf{F}$}

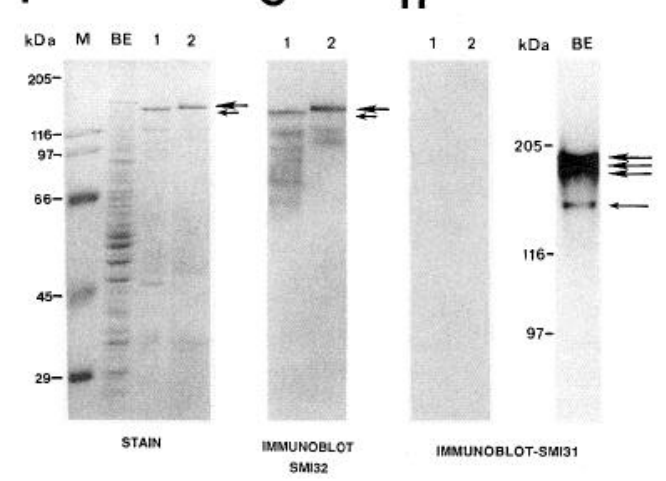

Figure 1. Structure and expression of NF genes in bacteria. $A$, Schematic structure of the mouse NF-H cDNA, indicating the two segments expressed in bacteria, as a fusion protein $(a)$ and as a nonfusion protein (b) (see Materials and Methods). $B$, Fragment $a$ was cloned in-frame with $\operatorname{trpE}$ gene in pATH1 and the resulting recombinant plasmid DNA was transformed into bacteria CAG456. Bacteria transformed with this plasmid were treated for $5 \mathrm{hr}$ with IAA to induce expression of the trpE-NF-H fusion polypeptide. After induction bacterial proteins were separated by SDS-PAGE through an $8.5 \%$ gel and identified by Coomassie blue staining. Lane $M$, protein molecular weight standards; lane 1 , bacterial proteins from a culture transformed with a control plasmid pATH 10 (induce expression of trpE, $37 \mathrm{kDa}$ ); lane 2, bacteria transformed with pATH1-NF-H express an approximately $150 \mathrm{kDa}$ bNF-H fusion protein. $C$, bNF-H fusion protein was induced from a 4 liter culture and the bacterial lysate applied to a DE52 anion-exchange column. Proteins that bound to the column were eluted with a salt gradient $(0-0.5 \mathrm{M} \mathrm{NaCl})$. A $1 / 500$ portion of the proteins eluted in alternate fractions of the column (numbered) was separated through an $8.5 \%$ SDS polyacrylamide gel and stained with Coomassie blue. $M$, protein mo- anti-mouse IgG (Organon Tekinika-Cappel, Durham, NC) in TBS buffer containing $5 \%$ milk and subsequently washed as described above. All filters were finally reacted for $1-2 \mathrm{hr}$ at $25^{\circ} \mathrm{C}$ with ${ }^{125}$ I-labeled Staphylococcus aureus protein $\mathrm{A}$ in wash buffer. The filters were then washed and exposed to $\mathrm{x}$-ray film (Kodak X-Omat AR film) at $-85^{\circ} \mathrm{C}$. Primary antibodies used for immunoblotting were SMI32 mouse monoclonal anti-nonphosphorylated neurofilaments ascites (Sternberger Monoclonals, Inc., Baltimore, MD), SMI31 mouse monoclonal anti-phosphoneurofilaments ascites (Sternberger Monoclonals), and a rabbit polyclonal anti-pan protein kinase $\mathrm{C}$ antibody (Upstate Biotechnology, Inc., Lake Placid, NY).

In vitro and in situ kinase assays. In vitro kinase assays were preformed in a $100 \mu \mathrm{l}$ reaction volume in a test tube. Typically, $1-5 \mu \mathrm{l}$ volumes of mouse brain lysate or individual affinity-purified fractions were assayed for kinases able to phosphorylate 10-20 $\mu \mathrm{g}$ of different NF proteins upon incubation in $20 \mathrm{~mm} \operatorname{MES}$ (pH 6.5), $10 \mathrm{~mm} \mathrm{MgCl}_{2}, 10$ mм $\beta$-glycerophosphate, $10 \mathrm{~mm}$ EGTA, and $1 \mathrm{~mm} \gamma-{ }^{32} \mathrm{P}$-ATP for 3-10 $\mathrm{hr}$ at $30^{\circ} \mathrm{C}$. After the reaction, NF proteins were immunoprecipitated (see below) and separated by SDS-PAGE. Native NF were not immunoprecipitated but separated directly by SDS-PAGE. Phosphorylation of NF proteins was determined by first staining the gels with Coomassie blue to identify the NF proteins; the gels were then dried and exposed to x-ray film. Autoradiograms were correlated with the stained gels in order to determine phosphorylation of the appropriate size NF proteins. Phosphorylation was measured by scanning the radioactive protein bands with a laser phosphoimager (Molecular Dynamics Phosphoimager).

The in situ gel kinase assay was performed essentially as described by Geahlean et al. (1986). In this procedure, $1-30 \mathrm{mg}$ of NF or casein protein was added to the resolving SDS polyacrylamide gel before polymerization. Samples that were assayed for kinase activity were boiled and separated by electrophoresis using the standard SDS-PAGE pro-

lecular weight standards. The position of the NF-H fusion protein is marked with an arrow. Please note that fraction 15 contained almost $100 \mathrm{mg}$ of approximately $65 \%$ pure bNF-H. This fraction was used to prepare the NF-H affinity column (see Materials and Methods). $D$, Expression of nonfusion NF proteins in bacteria. NF-L, NF-M, and NF-H cDNAs were cloned into pATH expression plasmids (see Materials and Methods). After induction bacterial proteins were separated by SDS-PAGE through an $8.5 \%$ gel and stained with Coomassie blue. Lane $M$, protein molecular weight standards; lane 1 , bacteria transformed with control pATH10 plasmid DNA induce expression of a 37 $\mathrm{kDa}$ trpE polypeptide; lane 2, bacteria transformed with pATH10.1NF-L (1-645 aa) plasmid DNA express the complete NF-L polypeptide as a nonfusion protein of the expected size (approximately $68 \mathrm{kDa}$; marked by the small arrow); lane 3, bacteria transformed with pATH2.1NF-M (1-845 aa) express little if any NF-M nonfusion protein; lane 4, bacteria transformed with pATH2.1-NF-H (69-1072 aa) express nonfusion NF-H protein of approximately $155 \mathrm{kDa}$ (marked with the large arrow). $E$, Purification of NF-H nonfusion protein. Fractions containing $\mathrm{NF}-\mathrm{H}$ nonfusion protein from the DE52 column were dissolved in $8 \mathrm{M}$ urea and $1 \%$ ampholytes, pH 3-10, and subjected to isoelectric focusing using the Bio-Rad Rotofor Cell. Fractions collected after focusing were analyzed on an $8.5 \%$ SDS-PAGE gel after staining with Coomassie blue. The position of NF-H nonfusion protein is indicated with an arrow. F$H$, The purified NF-H nonfusion and fusion proteins were separated by SDS-PAGE and immunoblotted with either phosphorylation-specific or nonphosphorylation-dependent NF antibody, SMI31 or SMI32, respectively. Lane $M$, protein molecular weight standards; lane $B E$, mouse brain extract; lane 1 , purified bNF-H fusion protein; lane 2 , purified NF-H nonfusion protein. $F$, Coomassie blue-stained gel. $G$, Immunoblot of proteins showing reaction of the bacterially expressed NF proteins with SMI32 antibody that recognizes nonphosphorylated NF-H protein. $H$, Immunoblot showing SMI31 antibody, which recognizes phosphorylation-dependent epitopes on NF-H, fails to recognize the bacterially expressed NF-H proteins. This antibody, however, recognizes both NF-H and NF-M proteins in mouse brain lysate (lane $B E$ ), both of which contain the Lys-Ser-Pro repeat sequences known to be part of the epitope recognized by this antibody. Please note that lane $B E$ in $H$ was fractionated on a $6.5 \%$ SDS-PAGE gel to resolve the different phosphorylated forms of NF-H that migrate as three major forms of about 190 $205 \mathrm{kDa}$. The fastest-migrating form (approximately $160 \mathrm{kDa}$ ) that is recognized by SMI31 is probably NF-M. 
cedure (see above). After electrophoresis the gel was incubated in $6 \mathbf{M}$ guanidine- $\mathrm{HCl}$ for $1 \mathrm{hr}$ at $20^{\circ} \mathrm{C}$ to denature proteins. The denaturant was then removed and the proteins slowly renatured by several changes with $20 \mathrm{~mm}$ MES (pH 6.5) and $5 \mathrm{~mm} 2$-mercaptoethanol at $4^{\circ} \mathrm{C}$ for at least $16 \mathrm{hr}$. After renaturation, the gel was preincubated in $20 \mathrm{mM}$ MES (pH 6.5), $10 \mathrm{~mm} \mathrm{MgCl}, 10 \mathrm{~mm} \beta$-glycerophosphate, $10 \mathrm{~mm}$ EGTA, and $1 \mathrm{~mm}$ DTT (KA buffer) at $30^{\circ} \mathrm{C}$ for $30 \mathrm{~min}$. The buffer was then exchanged for fresh buffer containing $250-500 \mu \mathrm{Ci}$ of radioactive $\gamma-{ }^{32} \mathrm{P}-$ ATP $(3000 \mathrm{Ci} / \mathrm{mmol}$; Amersham Corp., Arlington Heights, IL) and incubated for $2 \mathrm{hr}$ at $30^{\circ} \mathrm{C}$ with gentle shaking. Cold ATP was added to a final concentration of $1 \mathrm{~mm}$ and the incubation was continued for a further $2 \mathrm{hr}$. The gel was then washed extensively with $5 \%$ trichloroacetic acid (TCA), stained with Coomassie blue, dried, and exposed to $\mathrm{x}$-ray film. The radioactivity incorporated into individual bands was measured using the laser phosphoimage scanner.

Immunoprecipitation. A $5 \mathrm{ml}$ portion of Pansorbin cells (Calbiochem, La Jolla, CA) was first homogenized in $20 \mathrm{ml}$ of PBSE (standard phosphate buffered saline containing $1 \mathrm{~mm}$ EDTA) containing $5 \%(\mathrm{w} / \mathrm{v})$ BSA. The cells were then collected by centrifugation, washed twice with 20 $\mathrm{ml}$ of PBSE containing $0.5 \% \mathrm{NP} 40$, and incubated with $2.0 \mathrm{mg}$ of aflinity-purified rabbit anti-mouse IgG (Organon Tekinika-Cappel, Durham, NC) in $10 \mathrm{ml}$ of PBSE at $25^{\circ} \mathrm{C}$ for $30 \mathrm{~min}$. The cells were washed again with PBSE containing $0.5 \% \mathrm{NP} 40$, and finally resuspended in 5 $\mathrm{ml}$ of PBS and stored at $-85^{\circ} \mathrm{C}$. A $0.1 \mathrm{ml}$ aliquot of this suspension was diluted with $1 \mathrm{ml}$ of PBS and NF antibodies were then allowed to bind to the cell complex for $1.5 \mathrm{hr}$ by adding appropriate volumes (1$5 \mu \mathrm{l})$ of SMI31 antibody, SMI32 antibody, or a rabbit polyclonal antibody that we had raised using purified $\mathrm{bNF}-\mathrm{H}$ as immunogen. The cells were collected by centrifugation, washed, and then resuspended in $100 \mu \mathrm{l}$ of PBSE containing $0.5 \%$ NP40 and incubated for $20 \mathrm{hr}$ at $4^{\circ} \mathrm{C}$ with 5-10 $\mu$ l volumes of extracts from which NF protein precipitation was sought. Immunoprecipitation of native NF was performed using 5 $\mu \mathrm{l}$ of a freshly prepared sample of mouse brain lysate $(15 \mu \mathrm{g} / \mu \mathrm{l})$. After incubation the cells were collected by centrifugation. The pellet was then washed thrice and finally resuspended in $100 \mu \mathrm{l}$ of distilled water. Equal fractions of both the supernatant and pellet suspensions were separated by SDS-PAGE and analyzed for distribution of NF proteins by immunoblotting or for cofractionation of kinases by the in situ gel kinase assay.

\section{Results}

Since NF are the major cytoskeleton component in neurons we reasoned that they may act as a structural support for other functional proteins in the axon. Using affinity chromatography we demonstrate that many proteins do indeed bind to NF.

To isolate NF-binding proteins we used the affinity chromatography procedure that proved useful for isolating actinbinding proteins (Miller and Alberts, 1989; see also Miller et al., 1989) as well as microtubule-binding proteins (Kellogg et al., 1989). However, we were concerned that the procedure would yield a more complex mixture of NF-binding proteins because $\mathrm{NF}$ are much more irregular in structure compared to actin filaments or microtubules. We therefore concentrated on identifying proteins that bind to specific domains of NF. In this approach the tail domain of NF-H was first expressed as a recombinant protein and then used as an affinity ligand to purify NF-binding proteins.

\section{Expression of the carboxyl-terminal domain of NF-II in bacteria}

We chose to identify proteins that associate with the carboxylterminal domain of NF-H since this region has been implicated in cross-bridging NF and also contains the Lys-Ser-Pro repeat that is the major NF motif phosphorylated in vivo. Thus, the DNA fragment encoding the carboxyl-terminal sequences of mouse NF-H (see Fig. 1A), containing all of the Lys-Ser-Pro repeat sequences, was expressed as a $\operatorname{tr} p E$-fusion polypeptide in bacteria (Fig. 1 $B$; see Materials and Methods). As expected, the fusion protein appeared to be nonphosphorylated since it reacted strongly with SMI32 (Fig. $1 G$ ), a monoclonal antibody that reacts with dephosphorylated NF-H sequences (see Sternberger and Sternberger, 1983; Lee et al., 1988; Chin and Liem, 1990). The inability of bacterial kinases to phosphorylate LysSer-Pro sequences of NF-H was shown by absence of reactivity with SMI31 (Fig. 1 $H$ ), an antibody that requires phosphorylation of the serine residue of the Lys-Ser-Pro motif for its recognition (Lee at al., 1988). We will henceforth refer to this fusion polypeptide as bNF-H (for bacterially expressed NF-H fusion protein).

The fusion protein was purified by DEAE ion-exchange chromatography (Fig. 1C). The bNF-H fusion protein was identified both on the basis of its molecular weight on SDS gels (Fig. $1 F$; $\approx 150 \mathrm{kDa}$ ) and by its recognition with the NF-H antibody, SMI32 (Fig. $1 G$ ).

\section{Isolation of NF-binding proteins by affinity chromatography}

To isolate NF-binding proteins we prepared an affinity column onto which approximately $10 \mathrm{mg}$ of purified $\mathrm{bNF}-\mathrm{H}$ protein was covalently bound (see Fig. $2 A$ ). A control column was prepared, onto which $10 \mathrm{mg}$ of BSA was bound. Next a mouse brain extract was circulated over both columns (see Fig. $2 A$ and Materials and Methods). The columns were washed until no trace of protein was detected by UV absorbance in the flow through. Proteins bound to the columns were then eluted with a series of buffers over a range of salt concentrations (see Materials and Methods).

The complexity of proteins eluted was examined by silver staining following separation by electrophoresis through an $8.5 \%$ SDS polyacrylamide gel (see Fig. $2 B, C$ ). A significant number of proteins were eluted from the bNF-H column (see Fig. 2B). These proteins appeared to show specificity for binding to bNF-H since they were not eluted from the control BSA column. In fact, relatively few proteins were eluted from the BSA column (Fig. 2D). The latter were also eluted from the bNF-H column and thus were probably nonspecifically bound.

Proteins that specifically bound to the bNF-H column showed differences in their elution patterns, indicating a variety of binding affinities (see Fig. 2B). Few if any were eluted with ATP buffer (fractions 7-10). A small group was released with low salt $(0.1-0.3 \mathrm{M}$; fractions $11-18)$ but the major group was eluted with medium salt $(0.5 \mathrm{M}$; fractions $19-21)$. Interestingly, some proteins were eluted with high salt ( $>0.8 \mathrm{M}$; fractions $22-29$ ), which has been shown to be required to remove kinases from NF (Toru-Delbauffe and Pierre, 1983; Dosemeci et al., 1990).

It was difficult to determine the exact enrichment of each eluted protein after affinity chromatography since they have yet to be purified or characterized. However, it was clear that certain proteins were enriched upon affinity chromatography compared to their relative abundance in the original mouse brain extract. For example, the approximately 90 and $58 \mathrm{kDa}$ proteins (marked with arrows in Fig. $2 B$ ) were hardly detectable in mouse brain extracts, but were substantially enriched after affinity chromatography.

\section{NF-binding proteins are enriched in protein kinases}

Since a number of previous studies (see introductory remarks) had indicated that protein kinases copurify with NF, we investigated whether kinases were present in our NF affinity-purified fractions. We demonstrate that kinase activity was indeed present and moreover was significantly enriched upon affinity chromatography. 
A

ISOLATION OF NF-H ASSOCIATED PROTEINS BY AFFINITY.CHROMATOGRAPHY

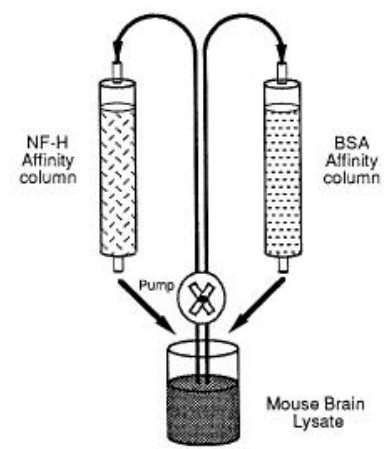

B
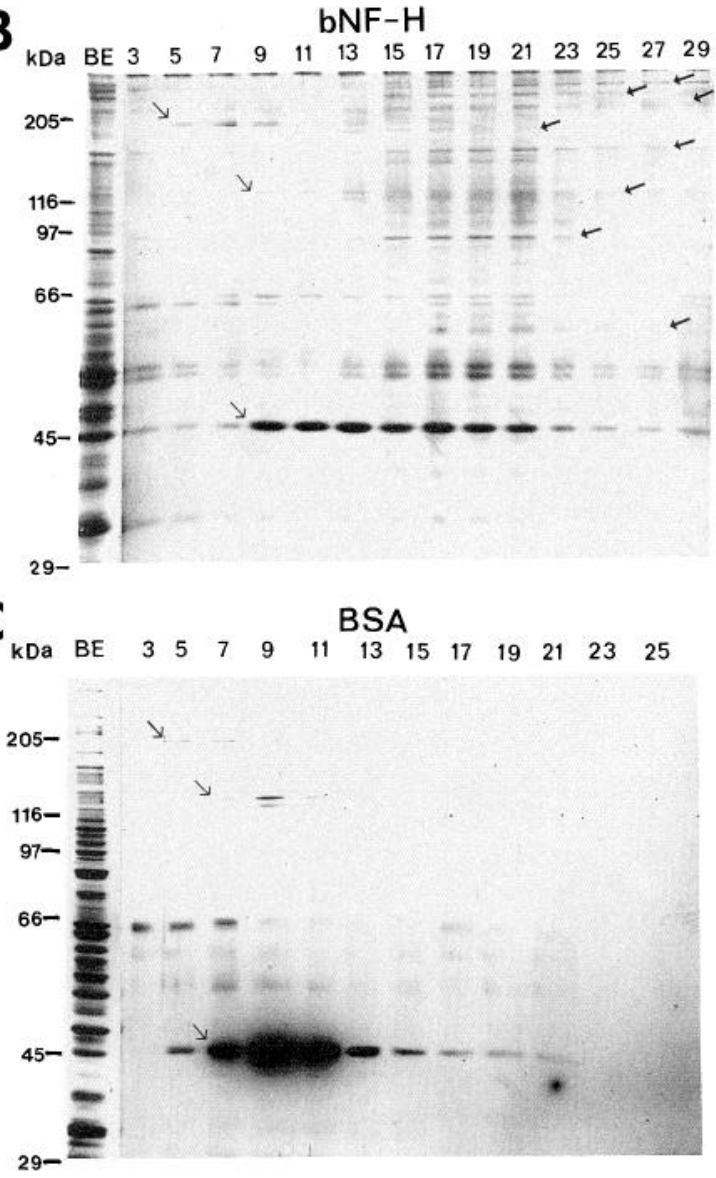

D

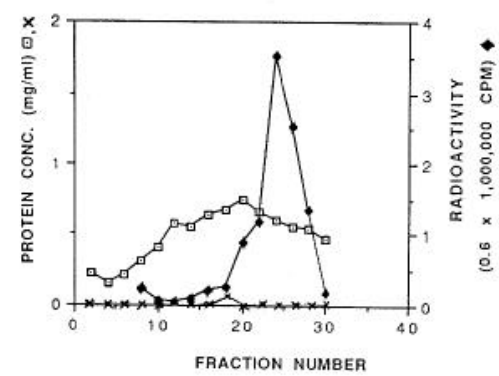

We used an in vitro assay containing bNF-H as substrate and radioactive $\gamma-{ }^{32} \mathrm{P}$-ATP to measure kinase activity present in crude mouse brain homogenate, the mouse brain extract loaded onto the columns (the homogenate after centrifugation at 45,000 $\times g$ ), and alternate fractions eluted from the bNF-H column. After the reaction the products were precipitated with TCA and the radioactivity incorporated determined by scintillation counting.

The profile of ${ }^{32} \mathrm{P}$ TCA-precipitable counts indicated that kinase activity was indeed present in the NF affinity-purified fractions (Fig. 2D). Furthermore, the majority of this activity was present in fractions eluted with medium-high salt $(>0.5 \mathrm{M}$; Fig. $2 D$ ). In fact, when compared with crude mouse homogenate, kinase activity was found to be enriched approximately 200fold after affinity chromatography (compare fraction 24 , $3,500,000{ }^{32} \mathrm{P}$ TCA precipitable $\mathrm{cpm} / \mu \mathrm{g}$ protein, with kinase activity in crude homogenate, $17,000 \mathrm{cpm} / \mu$ g protein).

\section{Substrate specificity of NF-binding kinases}

We next determined whether kinases recovered by affinity chromatography had any substrate preference for NF. Using a number of different substrates we demonstrated that the affinitypurified kinases are able to phosphorylate both native NF and bacterially expressed NF, although the former was phosphorylated to much higher stoichiometry.

The affinity-purified fractions were assayed for phosphorylation of purified $\mathrm{bNF}-\mathrm{H}$ protein using a standard in vitro kinase assay (Fig. $3 A$; see Materials and Methods). Thus, kinase activity of equivalent amounts of protein, in alternate fractions eluted from the NF-H column, was compared with that found in unfractionated mouse brain extract. After the assay, bNF-H was immunoprecipitated and phosphorylation of the approximately $150 \mathrm{kDa}$ bNF-H molecule was determined by phosphoimage laser densitometry of the appropriate ${ }^{32} \mathrm{P}$ radioactive bands following separation on SDS-polyacrylamide gels.

It was clear from this experiment that kinases capable of phosphorylating bNF-H were indeed recovered by affinity chromatography (see Fig. $3 A$ ). In fact, the peak affinity-purified fraction (fraction 23) contained as much as 18 -fold more bNF-H kinase activity than unfractionated brain extract. The ability of

Figure 2. Purification of NF-H-associated proteins by affinity chromatography. A, Schematic drawing of the isolation of NF-associated proteins. Purified bNF-H and BSA were each coupled to activated $\mathrm{CH}$ sepharose to form two different affinity columns. Mouse brain lysate was then circulated over the columns and proteins that bound to the columns were eluted with different buffers. $B$ and $C$, Mouse brain proteins that were eluted in different fractions (numbered) from the two affinity columns were separated by SDS-PAGE through an $8.5 \%$ gel and the gel was stained with silver. $B, \mathrm{bNF}-\mathrm{H}$ affinity-purified proteins. $C$, BSA affinity-purified proteins. $B E$, mouse brain extract. The conditions used to elute the fractions were as follows: fractions 3-7, wash buffer; fractions $7-10,5 \mathrm{~mm}$ ATP; fractions $11-14,0.1 \mathrm{M} \mathrm{KCl}$; fractions $15-$ $18,0.3 \mathrm{M} \mathrm{KCl}$; fractions $19-21,0.5 \mathrm{M} \mathrm{KCl}$; fractions $22-29,1 \mathrm{M} \mathrm{KCl}$. Proteins that were specifically eluted from the NF-H column are marked with the thick arrows, and proteins that appeared to elute from both columns with the thin arrows. Please note that gel containing BSA eluted proteins was developed longer to stain the small quantity of proteins that bound to this column (see protein elution profile in $D$ ). $D$. Amount of protein $(\mathrm{mg} / \mathrm{ml})$ eluted in individual fractions from the bNF-H $(\square)$ and BSA columns $(x)$, respectively. Equal samples of protein in alternate fractions ( $\diamond)$ eluted from the bNF-H column were assayed for kinase activity in an in vitro assay and the precipitable radioactive ${ }^{32} \mathrm{P}$ counts were determined. 


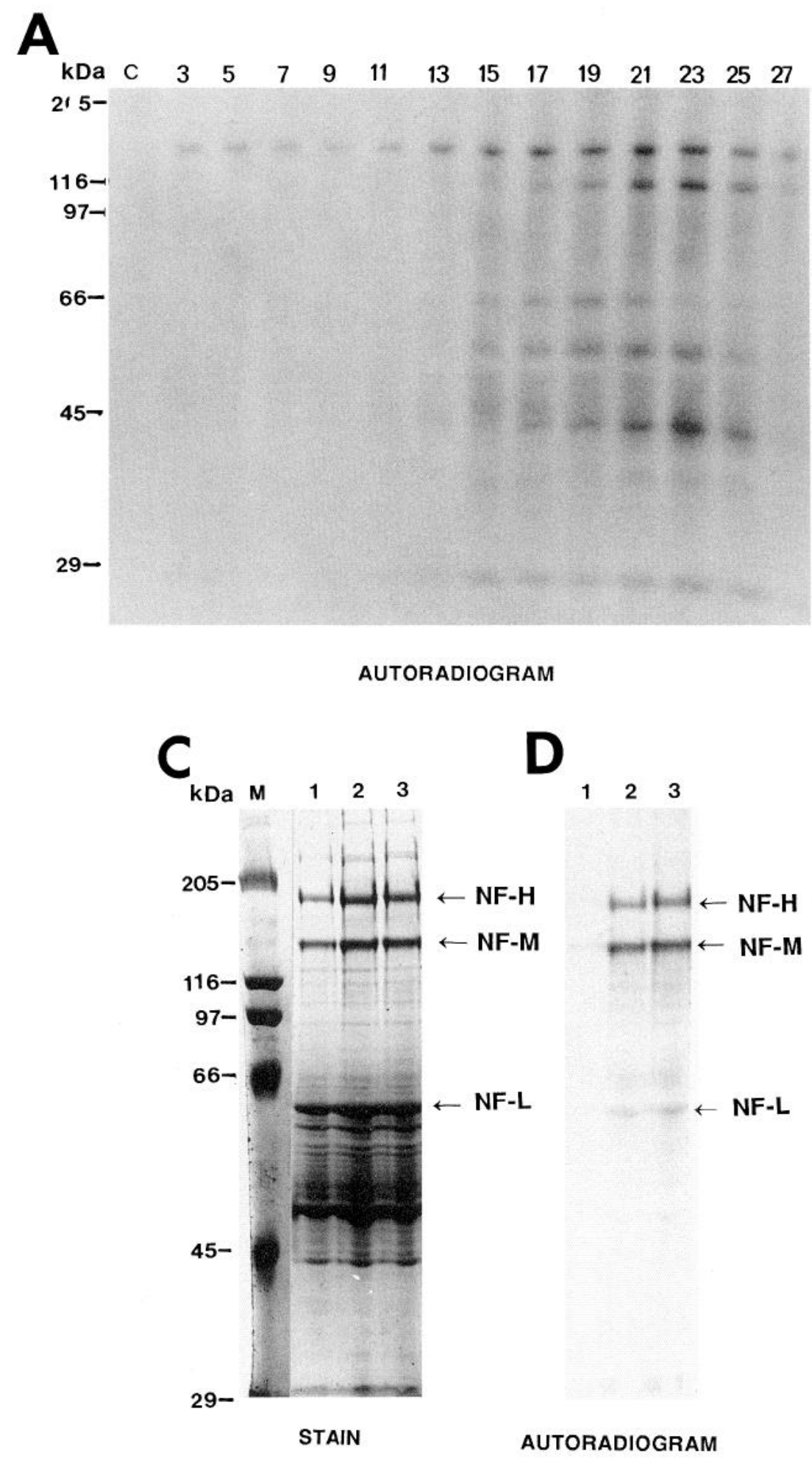

Figure 3. NF-H affinity-purified mouse brain proteins are enriched for NF kinases. Equal amounts of protein of a number of affinity-purified bNF-H fractions were assayed for phosphorylation of both native and bacterially expressed NF proteins in vitro (see Materials and Methods). $A$, Purified bNF-H fusion protein was used as substrate for this assay. After the assay, bNF-H was immunoprecipitated with a rabbit polyclonal antibody and the pellet fractions separated by SDS-PAGE on an $8.5 \%$ gel. The gel was stained with Coomassie blue to identify bNF-H (position is indicated with an arrow), dried, and exposed to $\mathrm{x}$-ray film. The autoradiogram shows the pattern of bNF-H phosphorylation by selected fractions (numbered). Lane $C$, kinase activity present in mouse brain homogenate before affinity chromatography. $B$, This autoradiogram was prepared as in $A$ except that the substrate used here was purified bacterially expressed nonfusion NF-H protein. The phosphorylation of this protein is indicated by the arrow. The fractions assayed for kinase activity were as follows: lane 1, mouse brain homogenate; lanes 2-4, fractions 20 , 22, and 24 , respectively. $C$, Native rat NF preparation was used as a substrate to assay the affinity-purified fractions for phosphorylation of individual NF subunits. After the assay the reaction mixture was separated by SDS-PAGE on an $8.5 \%$ gel. The migration of NF-H, NF-M, and NF-L (indicated) was then determined by Coomassie blue staining. Lane $M$, protein molecular weight standards; lane 1, incubated with total mouse brain extract; lane 2 , incubated with fraction 22 ; lane 3 , incubated with fraction $24 . D$ is the autoradiogram of the gel shown in $C$. 
Figure 4. Identification and characterization of individual protein kinases by the in situ gel kinase assay. $A-C$. Equal amounts of protein of three NF-H affinity-purified fractions were each resolved by SDS-PAGE through three different $8.5 \%$ polyacrylamide gels. After electrophoresis the gels were treated in a series of solutions to renature the proteins and to identify polypeptides with kinase activity (as described in Materials and Methods). After the in situ kinase assay the gels were washed, stained with Coomassie blue, dried, and exposed to $\mathrm{x}$-ray film. Lanes $1-3$ contain proteins from the affinity-purified fractions 20,22 , and 24 , respectively. $A$, Autoradiogram of standard SDS-PAGE gel in which no additional protein was polymerized into the gel matrix. $B$, Autoradiogram of the gel in which bNF-H protein $(1 \mathrm{mg} / \mathrm{ml})$ was polymerized into the gel matrix. $C$, Autoradiogram of gel in which casein $(1 \mathrm{mg} / \mathrm{ml})$ was polymerized into the gel matrix. The arrow indicates a $115 \mathrm{kDa}$ protein kinase, which we have termed NAK115, that showed the greatest increase in ${ }^{32} \mathrm{P}$ incorporation due to inclusion of bNF-H in the gel matrix. $D$, Profile of elution of individual kinases by NF-H affinity chromatography. Alternate fractions eluted from the bNF-H column were separated by SDS-PAGE on an $8.5 \%$ gel containing bNF-H protein $(0.5 \mathrm{mg} /$ $\mathrm{ml}$ ), and kinases were identified by the in situ gel assay (see above). The autoradiogram shows the profile of kinases in fractions 5-31 (numbered) that were eluted from the NF-H column. Please note that these fractions contain four major kinases, a $115 \mathrm{kDa}$ protein (large arrow) and three smaller proteins of approximately 95,89 , and $84 \mathrm{kDa}$ (small arrows) that eluted differently from the column. Lane $M$ contains protein molecular weight standards.
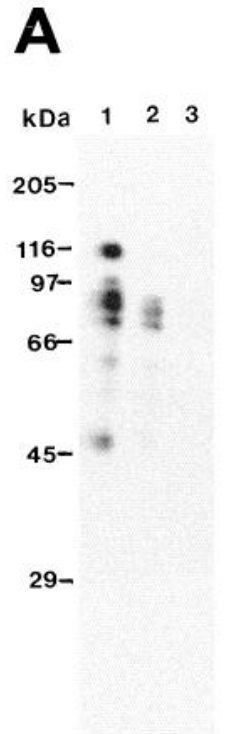

CONTROL

\section{B}
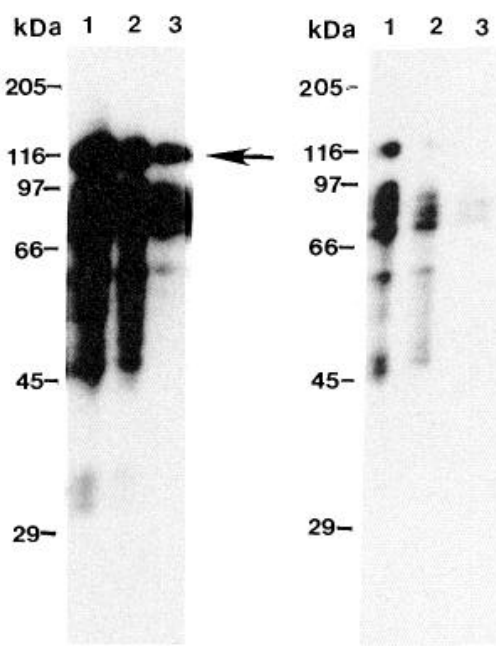

bNF-H
205-

116-

97-

66-

45-

29-

\section{CASEIN}

D
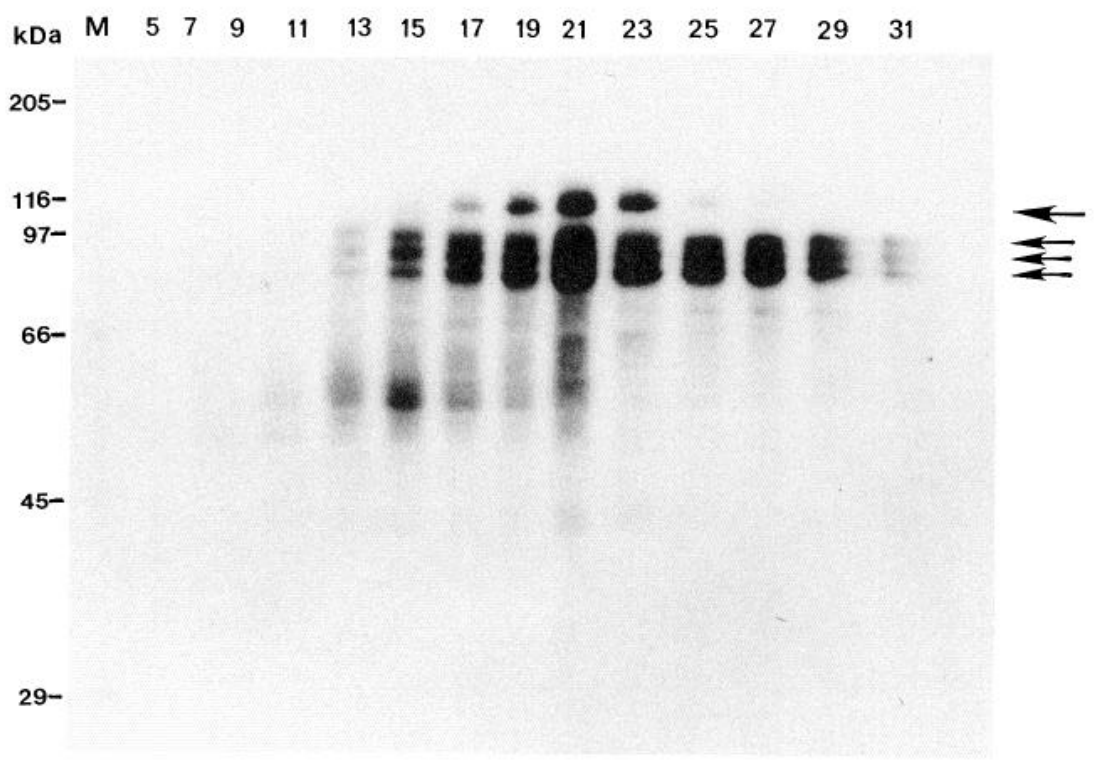

these kinases to phosphorylate bNF-H, which is not phosphorylated when expressed in bacteria (see Figs. $1 G, H ; 3 A, B$ ), is in contrast to the NF-H kinase isolated by Wible et al. (1989), which was unable to phosphorylate completely dephosphorylated NF-H.

Since phosphorylation of NF-H was previously shown to be affected by its prior phosphorylation state, we investigated if native NF-H would be a more effective substrate than bNF-H for phosphorylation by affinity-purified kinases. Thus, we used a purified rat spinal cord NF preparation, containing all three NF subunits, as substrate to assay the affinity-purified fractions for NF kinase activity. After phosphorylation in vitro, the NF subunits were separated by SDS-PAGE and identified by Coom- assie blue staining (Fig. $3 C$ ), and their corresponding phosphorylation was determined by autoradiography (Fig. $3 D$ ) and phosphoimage analysis (data not shown).

It was clearly evident from this analysis that affinity-purified kinases were able to phosphorylate efficiently not only NF-H but apparently all three NF subunits. Interestingly, tubulin and microtubule-associated proteins present in this preparation were phosphorylated poorly by the kinases. Further, partial dephosphorylation of rat NF with alkaline phosphatase did not result in any detectable difference in phosphorylation of the NF-H and NF-M subunits (there was a modest increase in NF-L phosphorylation), suggesting that native NF contain many sites that are accessible to phosphorylation (data not shown). Phosphor- 
ylation was accounted for entirely by the exogenously added kinases since heat-treated NF did not contain any detectable phosphorylation activity (data not shown).

Native NF-H was found to be phosphorylated approximately 35 -fold more efficiently than bNF-H, suggesting that the latter may indeed be compromised in its ability to be phosphorylated by the kinases (data not shown).

In vivo, the three NF subunits NF-H, NF-M, and NF-L are phosphorylated at approximately 40,15 , and 3 sites, respectively (see introductory remarks). It was therefore of interest to compare NF-H phosphorylation with that of the other two NF subunits. For this comparison the ${ }^{32} \mathrm{P}$ counts incorporated into each protein were calculated relative to the molar concentration of each subunit in the NF preparation (the molar concentration of the three subunits in this NF preparation was 1:2:4, for NFH:NF-M:NF-L, similar to that described by others) (Scott et al., 1985). Interestingly, NF-M was phosphorylated approximately twofold greater than NF-H. This phenomenon has also been found by others studying NF phosphorylation in vitro (see ToruDelbauffe and Pierre, 1983). As expected, NF-L was phosphorylated the least, in agreement with the relatively few phosphorylation sites found on this molecule. These results provided strong evidence that the affinity-purified fractions contained kinases capable of phosphorylating NF.

\section{Identification of novel NF-associated kinases by in situ kinase assay}

The above experiments did not distinguish whether multiple kinases were isolated by $\mathrm{NF}$ affinity chromatography. In this section we describe experiments designed to resolve these kinases.

A powerful method for separating and characterizing protein kinases is an in situ gel kinase assay developed by Geahlen et al. (1986; see also Hutchcroft et al., 1991). This method can detect individual kinases after separation on SDS-polyacrylamide gels. Further, since it is possible to trap different protein substrates in the SDS-PAGE gel matrix (Geahlen et al., 1986; Hutchcroft et al., 1991), this method further enables detection of kinases that phosphorylate different protein substrates.

We used the in situ gel assay to characterize kinases present in the NF-H affinity-purified fractions. A portion of lysate of three column fractions (fractions 20,22, and 24) were separated on three $8.5 \%$ SDS-polyacrylamide gels that differed with respect to the gel matrix used. The control gel was a standard polyacrylamide gel. The second gel contained bNF-H fusion protein polymerized in the gel matrix. The third gel contained dephosphorylated casein polymerized in the gel matrix. After electrophoresis the three gels were processed for kinase activity using $\gamma^{3}{ }^{32} \mathrm{P}-\mathrm{ATP}$ as a substrate (see Materials and Methods). The autoradiograms revealed that the affinity-purified fractions contained multiple polypeptides with kinase activity (Fig. 4). At least 15 polypeptides could be detected in fraction 20 in longer exposures of the autoradiogram. The proteins are true kinases and not ATP-binding proteins by the following criteria. First, cold ATP did not compete the radioactive ${ }^{32} \mathrm{P}$ from the gels. Second, in situ gels incubated with $\alpha{ }^{-32}$ P-ATP did not bind any detectable radioactivity (data not shown).

The number of kinases detected in the three gels was somewhat similar (compare Fig. $4 A-C$ ). Thus, the pattern of phosphorylated proteins in the gel to which no protein was added was weak but similar to the gels into which proteins had been polymerized. This indicates that most of the kinases were able to autophosphorylate. It is also possible, although unlikely, that phosphorylation of a comigrating protein could account for the phosphorylation seen in the control gel. However, in contrast to this low level of phosphorylation, kinase activity was increased significantly in the gel into which bNF-H fusion protein was coupled into the gel matrix (Fig. $4 B$ ) and to a lesser extent in the gel containing casein (Fig. $4 C$ ).

To quantify the increase in kinase activity, a laser phosphoimage scanner was used to measure the radioactivity of each major band in the three gels. The results revealed that a $115 \mathrm{kDa}$ kinase showed the most significant difference between gels. ${ }^{32} \mathrm{P}$ incorporation in this band was increased at least 25 -fold and 2 -fold in the bNF-H and casein gels, respectively. This indicated the $115 \mathrm{kDa}$ kinase demonstrated a greater specificity for bNF-H as substrate compared to casein. Although we cannot exclude the possibility of a specific increase in autophosphorylation upon addition of bNF-H, it seems more likely that the increase is due to direct phosphorylation of bNF-H in the gel. Moreover, other kinases had only a two- to fivefold increase in the gels, further suggesting that the 25 -fold increase was specific for the $115 \mathrm{kDa}$ kinase.

Using the in situ assay and bNF-H as substrate we next determined the elution profile of kinases from the bNF-H column. It was clear from this analysis that many kinases with different elution profiles were recovered by affinity chromatography (Fig. $4 D$ ). The most prominent activities detected were those associated with a $115 \mathrm{kDa}$ polypeptide and three smaller polypeptides with molecular weights of approximately 95,89 , and 84 $\mathrm{kDa}$ (Fig. $4 D$ ). Interestingly, both the $115 \mathrm{kDa}$ kinase and the three smaller kinases were eluted with a peak salt concentration of $0.5-0.7 \mathrm{~m}$. However, in contrast to the $115 \mathrm{kDa}$ kinase, the three smaller kinases were not completely eluted even with $1 \mathrm{M}$ salt. This complex elution profile suggests that this latter group of kinases may have multiple and variable binding affinities.

The molecular weights of the four prominent kinases detected by the in situ assay are substantially different from any of the kinases thought to phosphorylate NF, casein kinase I (Floyd et al., 1991), casein kinase II (Link et al., 1992), calcium/calmodulin-dependent kinase (Vallano et al., 1986), cdc or cdk2 kinases (Hisanaga et al., 1991), erk kinases (Drews et al., 1992), the $67 \mathrm{kDa}$ kinase doublet described by Wible et al., (1989), or the 36 and $40 \mathrm{kDa}$ kinases described by Roder and Ingram (1991). The size and heterogeneity of the kinases were, however, similar to PKC isoforms. We thus, tested for the presence of PKC by immunoblot analysis using a polyclonal antibody specific for PKC. PKC immunoreactivity, as expected, was detected in crudc mouse homogenate, but was not detected in any of the affinity-purified fractions (data not shown). These results suggest that PKC does not bind to the carboxyl-terminal sequences of NF-H. Further, the property and size of the kinases identified here appear distinct from any of the known NF kinases. For this reason we have termed these kinases NAK115 (for NFassociated kinase), NAK95, NAK89, and NAK84, respectively.

\section{Substrate specificity of NAK115}

We have begun to characterize the NF kinases identified in this study. In the previous section we demonstrated that there was a marked difference in NAK115 kinase activity depending on whether NF or casein was used as a substrate in gel assays. In this section we compared different NF substrates on NAK 115 activity using the in situ gel kinase assay. 

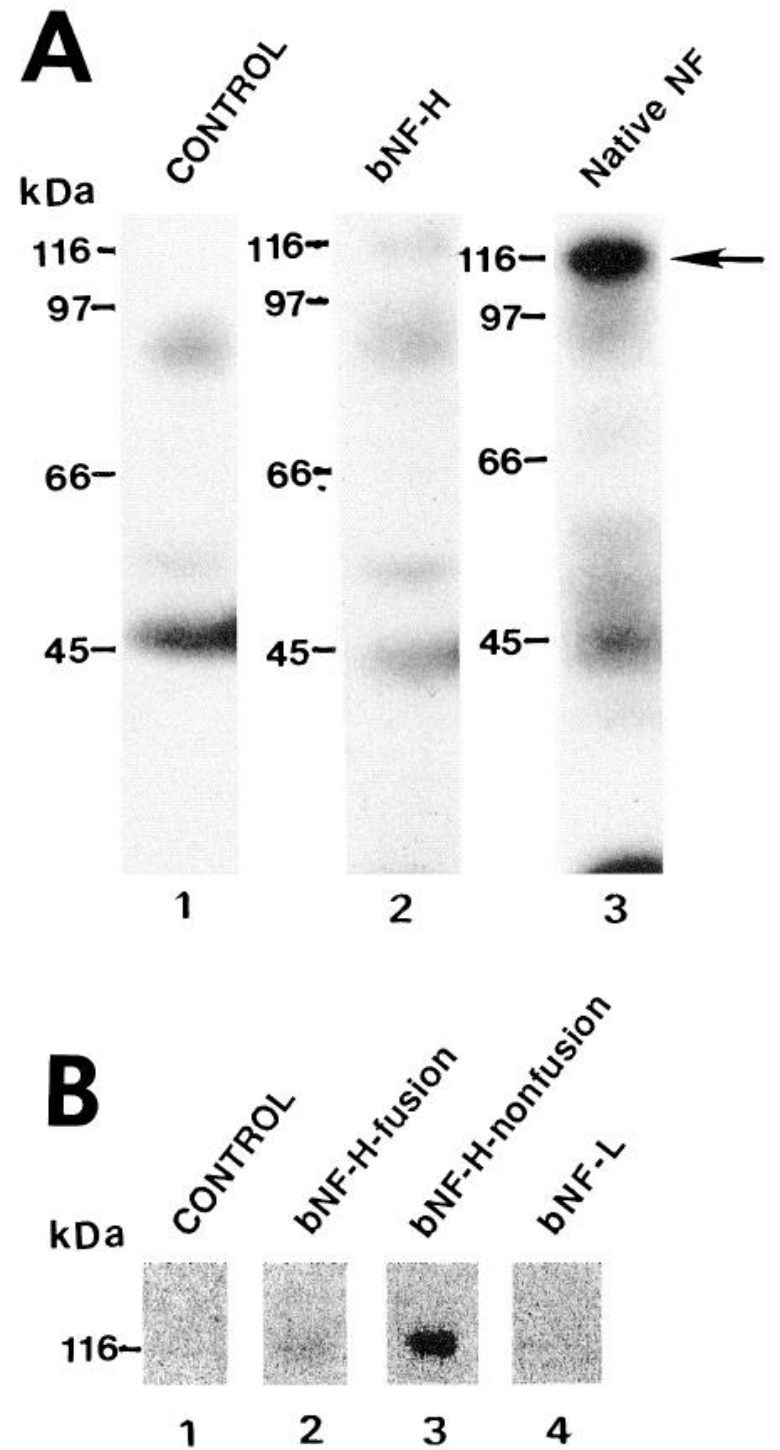

Figure 5. In situ gel kinase assay of different NF substrates. A number of different NF substrates were used in the in situ gel assay to determine the substrate preference for NAK115. A freshly prepared mouse brain extract was prepared and separated by electrophoresis through the different gels. After separation the gels were processed to determine kinase activity using the in situ gel assay. A, Autoradiogram of gels exposed for the same length of time, and treated in an identical fashion, to measure kinase activity. Lane 1, control gel in which no protein was embedded in the gel matrix; lane 2, gel in which purified bNF-H $(0.5$ $\mathrm{mg} / \mathrm{ml}$ ) was embedded in the gel matrix; lane 3 , gel in which native rat NF preparation was embedded in the gel matrix. The arrow indicates the $115 \mathrm{kDa}$ kinase, which showed the most significant increase in activity due to incorporation of NF substrates in the gel. $B$, Autoradiogram of the portion of the gel containing the $115 \mathrm{kDa}$ kinase of an experiment in which different NF subunits were compared using this assay. Lane 1, control gel; lane 2, gel in which bNF-H fusion protein was embedded into the gel matrix; lane 3 , gel in which purified bacterially expressed NF-H nonfusion protein was embedded in the gel matrix; lane 4, gel in which purified bacterially expressed NF-L was embedded in the gel matrix.

The efficiency of native NF as a substrate was first assessed. Thus, partially purified NF from rat spinal cord (Fig. $3 \mathrm{C}$ demonstrates the proteins found in this preparation) was solubilized in SDS buffer and polymerized in the polyacrylamide gel matrix.
A gel similar to that used before, containing bNF-H, and a control gel containing no added protein were also prepared. A partially purified mouse brain NAK 115 fraction was electrophoresed through the gels and kinase activity was determined. As had been found previously, NAK115 activity (measured as the ${ }^{32} \mathrm{P}$ incorporation of the band) in the gels varied according to the substrate immobilized in the gel matrix (Fig. 5A). NAK115 activity was approximately 10 -fold greater in the gel containing native NF, and 3.5-fold greater in the gel containing bNF-H, than in the control gel (see Fig. $5 A$ ). In this experiment ${ }^{32} \mathrm{P}$ incorporation was approximately sevenfold less upon addition of bNF-H than was found previously (Fig. 4), probably due to differences in bNF-H substrates used in the gels or due to the quality of the kinase fractions assayed. Nevertheless, NAK115 showed the biggest increase of all the kinases detected in the mouse brain fraction, confirming our earlier finding that this kinase showed the greatest affinity for NF as a substrate. It should be noted, however, that differences in phosphorylation of other kinases were also found.

The reason why native NF was better than bNF-H as a substrate for NAK115 kinase may have been due to differences in the NF-H proteins of the two substrates, or due to phosphorylation of proteins in addition to NF-H (like NF-M, NF-L, tubulin, or microtubule-associated proteins) in the former. The $\mathrm{NF}-\mathrm{H}$ substrate used in all the studies described so far was a fusion protein containing $37 \mathrm{kDa}$ of $\operatorname{trp} E$ sequences fused with 629 residues of NF-H sequences. We were concerned that the $\operatorname{trp} E$ portion interfered in some unknown way with phosphorylation of the fusion protein. Further, it was important to eliminate the possibility of phosphorylation of bacterial sequences that can occur when using fusion proteins (see Ward and Kirschner, 1990). In addition, it was possible that phosphorylation of bNF-H was poor because we had expressed only a small portion of NF-H in bacteria.

In order to circumvent these potential problems we expressed each of the three NF-subunits in bacteria as nonfusion proteins. We used the new pATH vectors we had constructed (Mercy et al., 1992) to express the complete NF-L, the complete NF-M, and almost the entire NF-H cDNAs (from residue 69 to its stop codon, i.e., 1004 aa) as nonfusion proteins in bacteria. Both NF-L and NF-H were efficiently expressed in bacteria (Fig. $1 D$, lanes 2 and 4, respectively). However, NF-M was expressed poorly for some unknown reason (Fig. 1D, lane 3 ). Since the in $s i t u$ gel assay requires abundant quantities of purified protein, at present we have been able to use only the former two as substrates for the in situ gel assay.

A newly prepared mouse brain extract was separated on four different gels that varied according to the protein polymerized into the gel matrix. After electrophoresis, the four gels were processed in an identical manner to measure gel kinase activity. The autoradiogram revealed that the greatest activity of the NAK 115 kinase was seen when NF-H nonfusion protein was used as substrate (Fig. $5 B$ ). bNF-H, as had been found previously, was the next best substrate but NF-L was a poor substrate (see Fig. $5 B$ ). These data provide further support for phosphorylation of NF-H by the $115 \mathrm{kDa}$ kinase.

Since the bacterially expressed NF-H nonfusion protein was a better substrate than bNF-H for NAK 115 by the in situ gel assay, we investigated whether the two would also be phosphorylated differently in vitro by kinases eluted from the affinitypurified column. Thus, equivalent portions of mouse brain extract and three fractions eluted from the column were assayed 

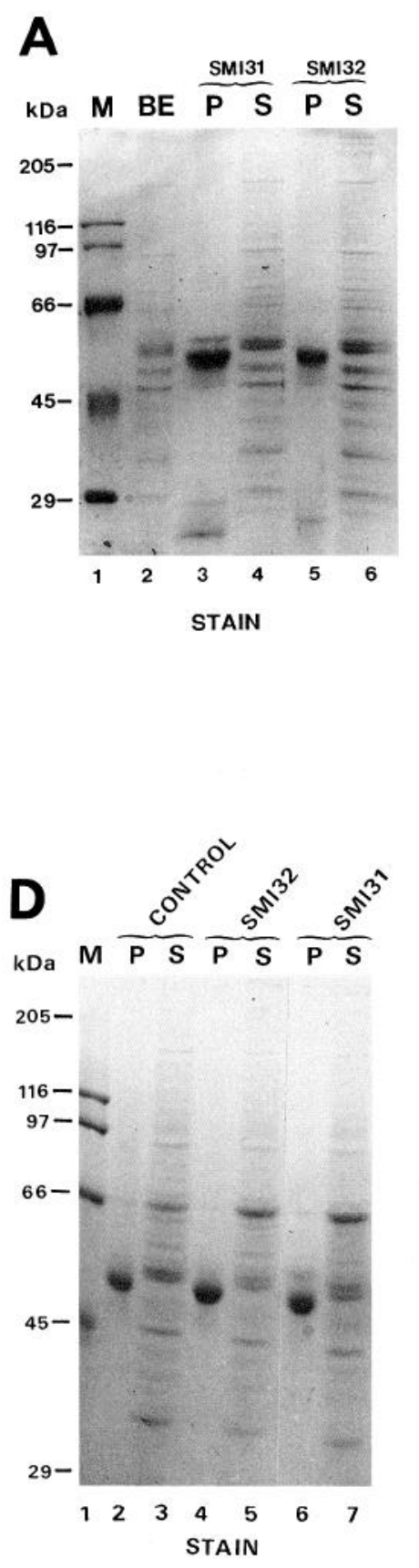
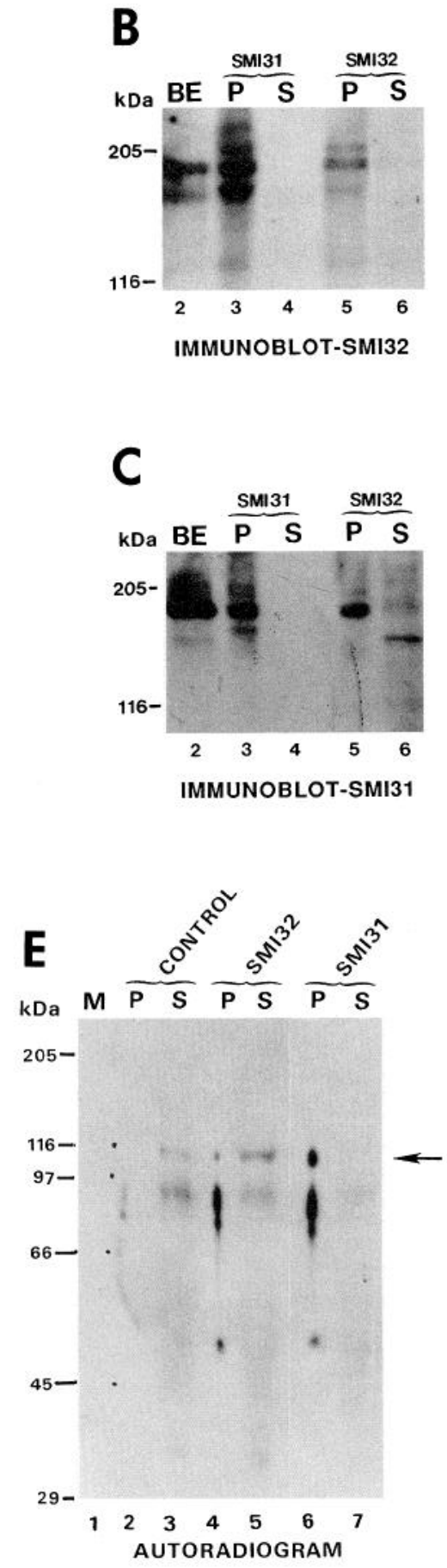

Figure 6. Demonstration that NAK 115 kinase is associated with NF in vivo. Antibodies that were known to react with NF were used to immunoprecipitate NF proteins. The pellet and supernatant fractions were then assayed to determine if NAK115 was coimmunoprecipitated with NF. Equal portions of mouse brain lysate $(75 \mu \mathrm{g})$ were incubated with Pansorbin cells containing either SMI31 (a monoclonal antibody that recognizes phosphorylationdependent epitopes of NF) or SMI32 (a monoclonal antibody that recognizes dephosphorylated NF). After incubation the cells were collected by centrifugation and equal portions of both the supernatant and pellet fractions were separated by SDS-PAGE. Gels containing these fractions were either stained with Coomassie blue $(A)$, immunoblotted with SMI32 $(B)$, immunoblotted with SMI31 $(C)$, or processed by the in situ gel kinase assay $(E)$. D shows a gel equivalent to $E$ but stained with Coomassie blue. $A-C$, Lane $M$, protein molecular weight standards; lane 2 , brain extract $(B E)$; lanes 3 and 4 , pellet $(P)$ and supernatant $(S)$ fractions after immunoprecipitation with antibody SMI 31 ; lanes 5 and $6, P$ and $S$ fractions after immunoprecipitation with antibody SMI32. $D$ and $E$, Lane 1 , protein molecular weight standards; lanes 2 and $3, P$ and $S$ fractions that had no antibody added; lanes 4 and 5 , and 6 and $7, P$ and $S$ fractions after immunoprecipitation with antibody SMI32 and SMI31, respectively. for phosphorylation of purified bNF-H and NF-H nonfusion proteins in an in vitro kinase reaction carried out in a test tube. After phosphorylation the proteins were immunoprecipitated and separated by SDS-PAGE, and the radioactivity incorporated into each protein was determined by autoradiography and by counting with a laser phosphoimage machine. These results indicated that the nonfusion protein was phosphorylated about twofold greater than bNF-H (data not shown). Interestingly, both substrates were phosphorylated about 7-fold and 18-fold greater by the affinity-purified kinases than crude mouse lysate, confirming NF kinases were substantially enriched after affinity chromatography (Fig. 3B).

\section{$N A K 115$ is associated with $N F-H$ in vivo}

We used an immunoprecipitation assay to determine whether NAK 115 kinase is associated with NF in vivo. We reasoned that if these proteins were physically associated in vivo, then upon immunoprecipitation of NF proteins, NAK 115 should be coimmunoprecipitated. We demonstrate that NAK 115 is indeed associated with NF using two different antibodies to immunoprecipitate NF.

We used two monoclonal antibodies, SMI31, which recognizes only phosphorylated epitopes of NF, and SMI32, which recognizes dephosphorylated epitopes of NF, to immunopre- 
A

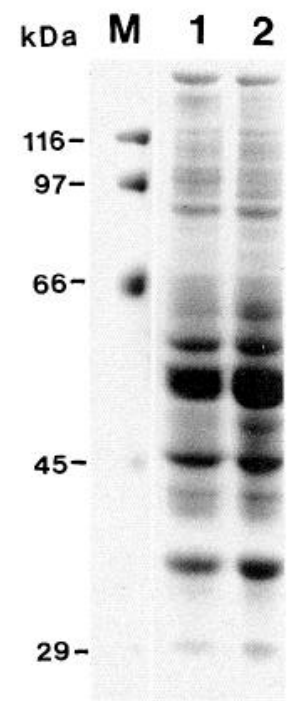

STAIN
B

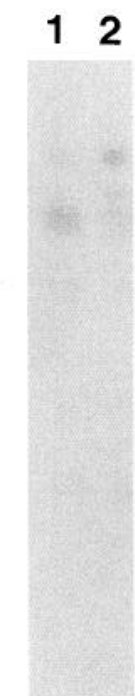

CONTROL
C

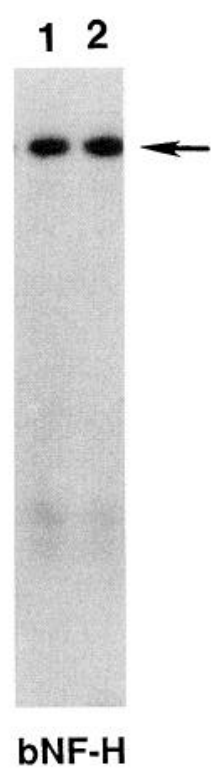

Figure 7. A kinase related to murine NAK115 is found in human brain lysates. The in situ gel kinase assay was used to detect kinases present in human brain. Human brain lysates from two individuals was separated through two different $8.5 \%$ SDS-polyacrylamide gels. One gel contained bNF-H $(1 \mathrm{mg} / \mathrm{ml})$ polymerized in the gel matrix and the other was the control that had no protein polymerized in the gel. After electrophoresis both gels were treated in an identical fashion, as described in Materials and Methods, to assay kinase activity in situ. The gels were then washed, dried, and exposed to x-ray film. $A$, Coomassie bluestained gel. $B$, Autoradiogram of kinases detected in the control gel by the in situ assay. $C$, Autoradiogram showing the presence of a $115 \mathrm{kDa}$ kinase (indicated with an arrow) in the gel containing bNF-H polymerized in its gel matrix. Both autoradiograms were exposed for $2 \mathrm{hr}$.

cipitate NF from a mouse brain lysate (see Materials and Methods). Upon immunoprecipitation equal portions of the pellet and supernatant fractions were separated on SDS-PAGE gels and analyzed for precipitation of NF by immunoblot analyses (Fig. $6 A-C$ ). A parallel set was analyzed for kinase activity by the in situ gel assay (Fig. 6D,E).

Immunoblot analyses revealed that, as expected, NF were present exclusively in the supernatant fraction and were not precipitated when anti-NF antibodies were not used for immunoprecipitation (Fig. 6A-C, lanes 2). Addition of anti-NF antibodies resulted in differential immunoprecipitation of NF When SMI31 was used almost all NF-H species detected by immunoblotting, using SMI31 or SMI32 antibodies, were immunoprecipitated since reactivity was found exclusively in the pellet fraction (Fig. $6 B, C$, lanes 3 ). In fact, no NF reactivity could be found in the supernatant fraction that contained the majority of the brain extract proteins (Fig. 6A-C, lanes 4). Similarly, when SMI32 was used all of the NFs detected by SMI32 were found in the pellet fraction (Fig. $6 \mathrm{~B}$, lane 5). However, in contrast to SMI31, which immunoprecipitated all detectable NF, SMI32 immunoprecipitated only a fraction (approximately $60 \%$ ) of the total NF detectable by SMI31 (Fig. $6 C$, lanes 5,6 ). Thus, the supernatant fraction contained a number of polypeptides, especially forms that migrated slower on SDS-polyacrylamide gels, that reacted with SMI31. Since SMI31 reacts with phosphorylated forms of NF-H and NF-M (see above), and SMI32 with dephosphorylated forms of these proteins, this re- sult indicates that most if not all NF-H and NF-M proteins expressed in mouse brain are phosphorylated to some extent. Further, the results suggest that approximately $40 \%$ of NF were phosphorylated extensively, presumably the slower migrating forms, and could not be immunoprecipitated by SMI32.

Having established that it was possible to immunoprecipitate NF with SMI31 and SMI32 antibodies we next investigated whether NAK1 15 kinase was associated with NF that had been precipitated. We thus assayed pellet and supernatant fractions after immunoprecipitation for kinase activity using the in situ gel kinase assay. For this assay we included BSA as a blocking agent to prevent nonspecific binding of the kinase with the immunoprecipitated complex. The inclusion of BSA resulted in an uneven spacing of proteins in some lanes of the SDS gel but the distribution of NAK1 15 kinase was not obscured by this outcome (Fig. 6E).

As expected NAK115 kinase was present in the supernatant along with NF when anti-NF antibodies were not included during immunoprecipitation (Fig. 6E, lanes 2, 3). However, its distribution changed in a manner similar to that of NF when anti-NF antibodies were used. Thus, NAK115 was found exclusively in the pellet, and was almost completely immunodepleted from the supernatant when SMI31 was used (see Fig. $6 E$, lanes 6,7$)$. Since all of the detectable NF was immunoprecipitated by this antibody, this suggests that almost all NAK 115 kinase is associated with NF in vivo.

In contrast to the complete immunoprecipitation of NAK 115 seen with SMI31, only a fraction of this activity was immunoprecipitated by SMI32 (Fig. 6E, lanes 4, 5). Approximately $25 \%$ of NAK 115 was precipitated by SMI32, which contrasts with the $60 \%$ fraction of NF precipitated by this antibody (compare with the immunoblot shown in Fig. $6 B, C$ ). We hypothesize that this difference is due to association of the kinase with predominantly phosphorylated forms of NF (see Discussion). These results, taken together, suggest that NAK 115 is associated with $\mathrm{NF}$ in vivo. In contrast to the specific immunoprecipitation of the NAK1 15 kinase, a number of other kinases (50-95 kDa in molecular weight) were immunoprecipitated by both SMI31 as well as SMI32 antibodies (see Fig. $6 E$ ). Moreover, these kinases were not completely removed from the supernatant. At present it is not clear if these kinases are proteins that are precipitated nonspecifically or whether they bind NF. Evidence in support of both these possibilities was obtained. For example, these kinases precipitated even when no NF-specific antibody was used (see Fig. $6 E$, lane 2). However, a greater fraction of these kinases was immunoprecipitated upon addition of SMI31 or SMI32 antibodies (see Fig. $6 E$, lanes 4,6 ). It should be possible to study the properties of these kinases once antibodies specific for the kinases are obtained.

\section{A protein related to mouse NAK115 is found in human brain}

It was of interest to know if a kinase similar to mouse NAK115 was expressed in humans since NF proteins are highly conserved across species (see Fliegner and Liem, 1991). Using the in situ gel assay we demonstrate that a kinase related to mouse NAK115 is present in human brain extracts.

Equivalent amounts of protein from two human brain homogenates were separated by electrophoresis through two different SDS-polyacrylamide gels. One gel contained bNF-H that had been polymerized in the gel matrix and the other was a standard gel containing no additional protein. After electrophoresis the gels were processed for protein kinase activity using the in situ gel assay. The autoradiogram revealed that protein 
kinases were present in the human brain extracts (Fig. $7 B, C$ ). Interestingly, the kinase patterns were somewhat similar to that found in crude mouse brain homogenate although minor differences were noted (compare Figs. $5 A, 7 B, C$; data not shown). More significantly, we found a kinase in human brain that was both identical in size to that of mouse NAK115 (see Fig. $7 C$, arrow) and which also incorporated more radioactive ${ }^{32} \mathrm{P}$ in the gel to which bNF-H was added as a substrate (compare Fig. $7 B, C$ ). However, the increase seen in ${ }^{32} \mathrm{P}$ incorporation was $14-$ fold, which is in contrast to the 25 -fold increase seen for the mouse enzyme. This difference may be due to differences in the two kinases and could reflect a preference of the mouse enzyme for the bacterially expressed mouse bNF-H substrate.

\section{Discussion}

We describe here the identification and characterization of a novel NF-associated kinase, NAK115. NAK115 was found to bind to NF by two different criteria. First, when NFs were immunoprecipitated from mouse brain extracts, NAK115 was precipitated along with NFs. Second, NAK 115 bound to NF-H in vitro by affinity chromatography. These findings represent the first characterization of a kinase that has been shown to associate dircctly with NF both in vivo and in vitro. Although the precisc sites on NF that are phosphorylated by NAK115 have yet to be mapped, our demonstration that NAK115 associates with NFs should provide clues as to the role of this kinase in NF phosphorylation.

NF phosphorylation is developmentally regulated (see Fliegner and Liem, 1991). Considerable evidence exists that suggests phosphorylated NF and nonphosphorylated NF are present in spatially distinct regions in the neuron. This segregation was first found by Sternberger and Sternberger (1983), who demonstrated that the former were restricted to axons whereas the latter were predominantly localized in the cell body. The apparent segregation of NF forms that are differently phosphorylated suggests that either the kinases and phosphatases that modify these proteins are spatially segregated, or NF proteins that are phosphorylated are rapidly transported into the axons. Although the mechanism underlying this segregation is not known, a number of recent studies support a mechanism by which cell-cell interactions determine the differential segregation of NF kinases and phosphatases in neurons. In particular, a role of Schwann cells (in PNS and, presumably, oligodendrocytes in CNS) has been implicated in this interaction. Thus, in trembler mice, in which mutations in the PMP-22 gene result in myelin deficiency of PNS axons, both NF phosphorylation and transport are decreased (de Waegh and Brady, 1990; de Waegh et al., 1992; Suter et al., 1992a,b). Other evidence supports the notion that NF kinases or phosphatases are in fact modulated by the axolemma in contact with Schwann cells. Thus, at the nodes of Ranvier of myelinated axons, which are characterized by an absence of myelination, NF phosphorylation is reduced (Mata et al., 1992). The reduction of NF phosphorylation seen in these two examples results in a concomitant reduction in axonal caliber. This reduction in caliber is also found during axotomy when NF synthesis decreases (Hoffman et al., 1984, 1985, 1987), and is in accord with the proposal that NF are intrinsic determinants of axonal caliber (Friede and Samorajski, 1970; Friede et al., 1971).

The findings described here of an association between NAK 115 and predominantly phosphorylated forms of NF suggest the NAK115 kinase may be compartmentalized in neurons. This would be in accord with the hypothesis that NF kinases are spatially distributed according to the levels of NF phosphorylation seen in neurons. We used the same two antibodies, SMI31 and SMI32, that have proved instrumental in uncovering differential NF phosphorylation to show that NAK115 was associated differently with the two NF forms immunoprecipitated by these antibodies. Interestingly, almost all of the detectable NAK 115 activity was coimmunoprecipitated when we used SMI31 but only approximately $25 \%$ was coimmunoprecipitated when SMI32 was used. This difference is most easily accounted for by the association of NAK115 with predominantly highly phosphorylated forms of NF.

The epitope recognized by SMI31 and SMI32 antibodies has been shown to be the Lys-Ser-Pro sequence that is repeated many times in both NF-H and NF-M. Phosphorylation of the Ser residue of this repeat is essential for recognition by SMI31, whereas the dephosphorylated epitope is recognized by SMI32. Two interesting properties emerge from the use of these antibodies for immunoprecipitation. First, almost all of the NF expressed in brain appears to be phosphorylated at least to some degree since most of the NF detected by immunoblotting could be precipitated by SMI31. Second, a subset of this NF population appears to be partially phosphorylated, accounting for precipitation of a portion of NF by SMI32, whereas the remaining subset that was not precipitated was presumably extensively phosphorylated. The substoichiometric amount of NAK 115 that was coprecipitated with NF by SMI32 suggests that NAK 115 is predominantly associated with heavily phosphorylated NF forms. Furthermore, the absence of NAK115 activity in the supernatant fraction after precipitation with SMI31 suggests that most of the kinase may be exclusively associated with NF and not with other cellular proteins. A remote possibility that we cannot exclude at present is that SMI31 immunoprecipitates NAK115 directly. This appears unlikely since SMI31 does not react with a $115 \mathrm{kDa}$ protein in mouse brain extracts in immunoblots (see Figs. $1 \mathrm{H}, 6 \mathrm{C}$ ).

The region on NF to which NAK 115 binds has not been established. For example, it is not known if the association we have found by immunoprecipitation is due to binding of NAK 115 to individual NF subunits (NF-H or NF-M, and possibly NFL) or binding to small NF fragments. Furthermore, our experiments do not distinguish whether NAK 115 binds to NF directly or whether it is associated with proteins that bind NF. The former would appear to be the case, as NAK 115 was isolated on the basis of its retention by an NF-H affinity column. Paradoxically, the bacterial NF-H coupled to the column is not phosphorylated, yet NAK115 bound to this polypeptide, contrary to its preferred association for phosphorylated NF inferred by the immunoprecipitation experiments. It is possible that NAK 115 binding is complex and the two procedures enable detection of different binding properties of this protein. In this regard it would be of interest to know if NAK 115 would bind more efficiently to an affinity column containing phosphorylated NF.

The in situ gel assay that we used to identify kinases in this study would not be expected to identify kinases that require multiple subunits for activity. However, the procedure enabled us to resolve and identify NAK 115 and at least three other polypeptides $(95,89$, and $84 \mathrm{kDa})$ with abundant kinase activity from the mixtures of proteins present in the affinity-purified fractions. At present we do not know if these kinases are single subunit kinases or the catalytic subunits of multiple subunit complexes. Their size and properties suggest these are novel 
kinases, unrelated to PKC by immunoblotting, and are likely to be involved in NF phosphorylation.

In addition to the association of NAK 115 with NF, another indicator that NAK1 15 is indeed involved in NF phosphorylation is the dramatic increase of incorporation of $\gamma^{-32} \mathrm{P}$-ATP seen in in situ gel assays when different NF substrates are immobilized in the gel matrix. Of all the kinases detected by the in situ gel assay, NAK 115 showed as much as a 25 -fold difference in ${ }^{32} \mathrm{P}$ incorporation when NF were incorporated into the gel matrix. This increase was not due to a nonspecific effect of including any protein in the gel since incorporation of casein, which is an excellent substrate for a number of kinases that phosphorylate NF, caused only a twofold increase in activity. The most likely explanation for the dramatic increase in ${ }^{32} \mathrm{P}$ incorporation seen with NAK 115 is the direct phosphorylation of NF present in the gel matrix. This increase was seen when both native and purificd bacterially cxpressed protcins were used for the in situ gel assay. However, the increase was at least three-fold smaller when bacterially expressed substrates were used. This difference may in part be explained by a preference for the kinase for phosphorylated NF substrates. Indeed, Wible et al. (1989) have identified an NF-H-specific kinase activity, which copurifies as a $67 \mathrm{kDa}$ doublet, that is able to phosphorylate partially phosphorylated NF-H but is unable to phosphorylate completely dephosphorylated NF-H. Interestingly, we have found a similar effect on NF-H phosphorylation when we compared the phosphorylation of native NF with that of bacterially expressed proteins, both by the in situ gel and in vitro kinase assays. Thus, when the affinity-purified fractions were assayed in a test tube for phosphorylation of bNF-H or bacterially expressed NF-H nonfusion proteins, they were both phosphorylated approximately 15-35-fold less compared with native NF-H (data not shown). Although both of the former substrates were phosphorylated less efficiently, the profile of phosphorylation paralleled that of NAK115 kinase activity (compare Figs. $3 A, 4 D$ ). Therefore, using purified bacterially expressed NF proteins we have unequivocally demonstrated that the affinity-purified fractions contain kinases that are able to phosphorylate completely dephosphorylated NF proteins.

There are a number of properties that make NAK 115 interesting in terms of NF kinases. It has a large molecular weight and a pI of about 4.8 (data not shown) and is able to autophosphorylate. It appears to be an effector-independent kinase since we have not observed any cofactor requirement for its activity (data not shown). Furthermore, a kinase of identical size and properties is present in human brain. This would be expected of a kinase that plays an important role in phosphorylation of highly conserved proteins. A comparison of different NF substrates reveals that NF-L is not an effective substrate but that NF-H proteins are good substrates (we have not tested NF-M as a substrate due to difficulties in expressing NF-M in bacteria). Interestingly, the nonfusion NF-H protein was a better substrate than the fusion protein. It is possible that the former is a better substrate due to lack of $\operatorname{tr} E E$ sequences or the presence of additional NF-H sequences. However, it was not surprising that NF-L was a poor substrate in the gel kinase assay since in vivo it is phosphorylated at a molar ratio of 1:50 compared to NF-H. Additional properties should emerge as this and other kinases that phosphorylate NF are purified. In this regard the in situ gel assay should be useful to identify kinases that phosphorylate NF-L and NF-M.

Finally, we would like to speculate on the identity of the other proteins that were isolated by bNF-H affinity chromatography. Using this approach we have been able to show that a number of proteins including kinases bind to the carboxyl-terminal region of NF-H. Binding of proteins to this region is not surprising since the tail of NF-H forms lateral projections from the filament core and thus would be expected to interact with proteins in the axonal cytoplasm. Apart from the protein kinases that are known to phosphorylate this region of NF, the identity of other NFbinding proteins is not known. In fact, apart from this study, relatively little is known of proteins that interact with NF. The best-characterized NF-associated protein is MAP2, which is thought to facilitate binding of NF with microtubules (see Fliegner and Liem, 1991; Hirokawa, 1991). Another protein, fodrin (brain spectrin), has been shown to bind NF and may thus link NF with other neuronal cytoskeletal elements (Frappier et al., 1987). An indication that NF may provide support for other functional protcins is the finding that synapsin $I$ is associated with NF (Goldenring et al., 1986; Steiner et al., 1987). From these studies it appears that the NF-binding proteins identified in this study could play diverse roles such as linking NF with the cytoskeleton, modifying NF, or using NF as a functional support or for their transport along the axon. We are presently preparing monoclonal antibodies against these proteins in order to characterize them further. A study of NF and their associated proteins should provide clues as to the role of these proteins in neuronal function and in diseases associated with disruption of the cytoskeleton.

\section{References}

Arai H, Lee VM-Y, Otvos L, Greenberg BD, Lowery DE, Sharma SK, Schmidt ML, Trojanowski JQ (1990) Defined neurofilament, $\tau$, and $\beta$-amyloid precursor protein epitopes distinguish Alzheimer from nonAlzheimer senile plaques. Proc Natl Acad Sci USA 87:2249-2253.

Caputo CB, Sygowski LA, Brunner WF, Scott CW, Salama A (1989) Properties of several protein kinases that copurify with spinal cord neurofilaments. Biochim Biophys Acta 1012:299-307.

Carden MJ, Schlaepfer WW, Lee VM-Y (1985) The structure, biochemical properties and immunogenicity of neurofilament peripheral regions are determined by phosphorylation state. J Biol Chem 260: 9805-9817.

Carden MJ, Trojanowski JQ, Schlaepfer WW, Lee VM-Y (1987) Twostage expression of neurofilament polypeptides during rat neurogenesis with early establishment of adult phosphorylation patterns. $J$ Neurosci 7:3489-3504.

Chin SSM, Liem RKH (1990) Transfected rat high molecular-weight neurofilament (NF-H) coassembles with vimentin in a predominantly nonphosphorylated form. J Neurosci 10:3714-3726.

de Waegh SM, Brady ST (1990) Altered slow axonal transport and regeneration in a myelin-deficient mutant mouse: the trembler as an in vivo model for Schwann Cell-axon interactions. J Neurosci 10: 1855-1865.

de Waegh SM, Lee VM-Y, Brady ST (1992) Local modulation of neurofilament phosphorylation, axonal caliber, and slow axonal transport by myelinating Schwann cells. Cell 68:451-463.

Dosemeci A, Floyd CC, Pant HC (1990) Characterization of neurofilament-associated protein kinase activities from bovine spinal cord. Cell Mol Neurobiol 10:369-382.

Drews G, Lichtenberg-Kraag B, Doring F, Mandelkow E-M, Biernat J, Goris J, Doree M, Mandelkow E (1992) Mitogen activated protein (MAP) kinase transforms tau protein into an Alzheimer-like state. EMBO J 11:2131-2138.

Fliegner KH, Liem RK (1991) Cellular and molecular biology of neuronal intermediate filaments. Int Rev Cytol 131:109-167.

Floyd CC, Grant P, Gallant PE, Pant HC (1991) Principal neurofilament-associated protein kinase in squid axoplasm is related to casein kinase I. J Biol Chem 266:4987-4994.

Frappier T, Regnouf F, Pradel LA (1987) Binding of brain spectrin to the $70 \mathrm{kDa}$ neurofilament subunit protein. Eur J Biochem 169: 651-657. 
Friede RL, Samorajski T (1970) Axon caliber related to neurofilaments and microtubules in sciatic nerve fibers of rats and mice. Anat Rec 167:379-388.

Friede RL, Miyaghishi T, Hu KH (1971) Axon caliber, neurofilaments, microtubules, sheath thickness and cholesterol in cat optic nerve fibers. J Anat 108:365-373.

Geahlean RL, Anostario M, Low PS, Harrison ML (1986) Detection of protein kinase activity in sodium dodecyl sulphate-polyacrylamide gels. Anal Biochem 153:151-158.

Geisler N, Vandekerckhove J, Weber K (1987) Location and sequence characterization of the major phosphorylation sites of the high molecular mass neurofilament proteins $M$ and H. FEBS Lett 221:403407.

Goldenring JR, Lasher RS, Vallano ML, Ueda T, Naito SS, Sternberger NH, Sternberger LA, DeLorenzo RJ (1986) Association of synapsin I with neuronal cytoskeleton. J Biol Chem 261:8495-8504.

Hall GF, Kosik KS (1993) Axotomy-induced neurofilament phosphorylation is inhibited in situ by microinjection of PKA and PKC inhibitors into identified lamprey neurons. Neuron 10:613-625.

Hirokawa N (1991) Molecular architecture and dynamics of the neuronal cytoskeleton. In: The neuronal cytoskeleton (Burgoyne RD, ed), pp 5-74. New York: Wiley-Liss.

Hisanaga S-I, Kusubata M, Okumura E, Kishimoto T (1991) Phosphorylation of neurofilament $\mathrm{H}$ subunit at the tail domain by $\mathrm{cdc} 2$ kinase dissociates the association with microtubules. J Biol Chem 266:21798-21803.

Hoffman PN, Lasek RJ (1975) The slow component of axonal transport: identification of the major structural polypeptides of the axon and their generality among mammalian neurons. J Cell Biol 66:351366.

Hoffman PN, Griffin JW, Price DL (1984) Control of axonal caliber by neurofilament transport. J Cell Biol 99:705-714.

Hoffman PN, Thompson GW, Griffin JW, Price DL (1985) Changes in neurofilament transport coincide temporally with alterations in the caliber of axons in regenerating motor fibers. J Cell Biol 101:13321340.

Hoffman PN, Cleveland DW, Griffin JW, Landes PW, Cowan NJ, Price DL (1987) Neurofilament gene expression: a major determinant of axonal caliber. Proc Natl Acad Sci USA 84:3472-3476.

Hutchcroft JE, Anostario M, Harrison ML, Geahlen RL (1991) Renaturation and assay of protein kinases after electrophoresis in sodium dodecyl sulphate-polyacrylamide gels. Methods Enzymol 200:417423.

Julien J-P, Mushynski WE (1982) Multiple phosphorylation sites in mammalian neurofilament polypeptides. J Biol Chem 257:1046710470.

Julien J-P, Mushynski WE (1983) The distribution of phosphorylation sites among identified proteolytic fragments of mammalian neurofilaments. J Biol Chem 258:4019-4025.

Julien J-P, Meijer D, Hurst J, Grosveld F (1986) Cloning and developmental expression of the murine neurofilament gene family. Mol Brain Res 1:243-250.

Julien J-P, Cote F, Beaudet L, Sidky L, Flavell D, Grosveld F, Mushynski WE (1988) Sequence and structure of the mouse gene coding for the largest neurofilament subunit. Gene 68:307-314.

Kellogg DR, Field CM, Alberts BM (1989) Identification of microtubulc-associatcd protcins in the centrosome, spindle, and kinetochore of the early Drosophila embryo. J Cell Biol 109:2977-2991.

Koerner TJ, Hill JE, Myers AM, Tzagoloff A (1991) High-expression

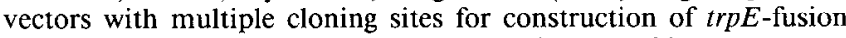
genes: pATH vectors. Methods Enzymol 194:477-490.

Laemmli UK (1970) Cleavage of structural proteins during the assembly of the head of bacteriophage T4. Nature 227:680-685.

Lee VM-Y, Otvos L, Carden MJ, Dietzschold MB, Lazzarini RZ (1988) Identification of the major multiphosphorylation site in mammalian neurofilaments. Proc Natl Acad Sci USA 85:1998-2002.

Link WT, Grant P, Hidaka H, Pant HC (1992) Casein kinases I and II from squid brain exhibit selective neurofilament phosphorylation. Mol Cell Neurosci 3:548-558.

Mata M, Kupina N, Fink DJ (1992) Phosphorylation-dependent neurofilament cpitopes are reduced at the node of ranvier. $J$ Neurocytol 21:199-210.

Mercy MR, Troncoso JC, Monteiro MJ (1992) A new series of trpE vectors that enable high expression of nonfusion protein in bacteria. Protein Expression Purif 3:57-64.
Miller KG, Alberts BM (1989) F-actin affinity chromatography: technique for isolating previously unidentified actin-binding proteins. Proc Natl Acad Sci USA 86:4808-4812.

Miller KG, Field CM, Alberts BM (1989) Actin-binding proteins from Drosophila embryos: a complex network of interacting proteins detected by F-actin affinity chromatography. J Cell Biol 109:2963-2975.

Morrissey JH (1981) Silver stain for proteins in polyacrylamide gels: a modified procedure with enhanced uniform sensitivity. Anal Biochem 117:307-310.

Napolitano EW, Chin SS, Colman DR, Liem RK (1987) Complete amino acid sequence and in vitro expression of rat NF-M, the middle molecular weight neurofilament protein. J Neurosci 7:2590-2599.

Nixon RA, Sihag RK (1991) Neurofilament phosphorylation: a new look at regulation and function. Trends Neurosci 14:501-505.

Pant IIC, Gallant PE, Gainer H (1986) Characterization of a cyclic nucleotide- and calcium-independent neurofilament protein kinase activity in axoplasm from the squid giant axon. J Biol Chem 261: 2968-2977.

Roder HM, Ingram VM (1991) Two novel kinases phosphorylate tau and the KSP site of heavy neurofilament subunits in high stoichiometric ratios. J Neurosci 11:3325-3343.

Schmidt ML, Carden MJ, Lee VM-Y, Trojanowski JQ (1987) Phosphate dependent and independent neurofilament epitopes in the axonal swellings of patients with motor neuron disease and controls. Lab Invest 56:282-294.

Scott D, Smith KE, O'Brien BJ, Angelides KJ (1985) Characterization of mammalian neurofilament triplet proteins. J Biol Chem 260:1073610747.

Shaw G (1991) Ncurofilament proteins. In: The neuronal cytoskeleton (Burgoyne RD, eds), pp 185-214. New York: Wiley-Liss.

Shaw G, Weber K (1982) Differential expression of neurofilament triplet proteins in brain development. Nature 298:277-279.

Steiner JP, Ling E, Bennet V (1987) Nearest neighbour analysis for brain synapsin I. J Biol Chem 262:905-914.

Sternberger NH, Sternberger LA (1983) Monoclonal antibodies distinguish phosphorylated and nonphosphorylated forms of neurofilaments in situ. Proc Natl Acad Sci USA 80:6126-6130.

Sternberger NH, Sternberger LA, Ulrich J (1985) Aberrant neurofilament phosphorylation in Alzheimer disease. Proc Natl Acad Sci USA 82:4274-4276.

Suter U, Welcher AA, Ozcelik T, Snipes GJ, Kosaras B, Francke U, Billings-Garliardi S, Sidman RL, Shooter EM (1992a) Trembler mouse carrics a point mutation in a myelin gene. Nature 356:241244.

Suter U, Moskow JJ, Welcher AA, Snipes GJ, Kosaras B, Sidman RL, Buchberg AM, Shooter EM (1992b) A leucine-to-proline mutation in the putative first transmembrane domain of the 22-kDa peripheral myelin protein in the trembler-J mouse. Proc Natl Acad Sci USA 89: $4382-4386$.

Toru-Delbauffe D, Pierre M (1983) A rat brain protein kinase phosphorylating specifically neurofilaments. FEBS Lett 162:230-234.

Toru-Delbauffe D, Pierre M, Osty J, Chantoux F, Francon J (1986) Properties of neurofilament protein kinase. Biochem J 235:283-289.

Trojanowski JQ, Schmidt ML, Shin R-W, Bramblett GT, Rao D, Lee VM-Y (1993) Altered tau and neurofilament proteins in neurodegenerative diseases: diagnostic implications for Alzheimer's disease and Lewy body dementias. Brain Pathol 3:45-54.

Vallano ML, Goldenring JR, Lasher RS, Delorenzo RJ (1986) Association of calcium/calmodulin-dependent kinase with cytoskeletal preparations: phosphorylation of tubulin, neurofilament, and microtubule-associated proteins. Ann NY Acad Sci 466:357-375.

Ward GE, Kirschner MW (1990) Identification of cell cycle-regulated phosphorylation sites on nuclear lamin C. Cell 61:56l-577.

Wible BA, Smith KE, Angelides KJ (1989) Resolution and purification of a neurofilament-specific kinase. Proc Natl Acad Sci USA 568:209218.

Xu Z, Liu W-S, Willard M (1990) Identification of serine 473 as a major phosphorylation site in the neurofilament polypeptide NF-L. J Neurosci 10:1838-1846.

Xu Z, Liu W-S, Willard MB (1992) Identification of six phosphorylation sites in the $\mathrm{COOH}$-terminal tail region of the rat neurofilament protein M. J Biol Chem 267:4467-4471.

Zhang H, Sternberger NH, Rubinstein LJ, Herman MM, Binder LI, Sternberger LA (1989) Abruormal processing of multiple proteins in Alzheimer disease. Proc Natl Acad Sci USA 86:8045-8049. 